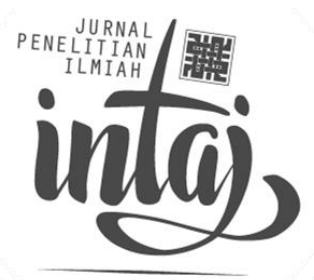

\title{
Relasi Rumah Tangga Komunitas Santri Pelaku Pernikahan Dini
}

\author{
Muhammad Adib (m.adib@alqolam.ac.id) \\ Siti A’isyah (ibuafasda@gmail.com) \\ Institut Agama Islam Al-Qolam Malang
}

(Received: September 2018 / Revised: Januari 2019 / Accepted: Maret 2019)

\begin{abstract}
The focus of this research is about the pattern of relationships that are built in the households resulting from early marriage among the santri community in three villages in Gondanglegi District, Malang Regency, namely Ganjaran, Putukrejo and Sukosari - three villages with the strongest pesantren base in Gondanglegi region. The starting point is the strengthening of the assumption that early marriage is one of the main causes of domestic violence - where women are always victims, divorce and even trafficking in women and children. The study using this phenomenological approach concluded that the pattern of relationships built in the households resulting from early marriage of the santri community does require an adaptation process, from submission to agreement, with the uniqueness of each partner. However, the households they cultivate persist and last normally as households in general. The teachings of religion and the social values about household that they hold firm, as part of the typical character of the santri community, are one of the strength factors.
\end{abstract}

Keywords: Household Relationship, Pattern, Santri Community, Early Marriage. 


\section{PENDAHULUAN}

Angka pernikahan dini di wilayah Kabupaten Malang Jawa Timur terhitung cukup tinggi, yakni mencapai $26,9 \%$ dari rata-rata total 23.000 pasangan per tahun. ${ }^{1} \mathrm{Hal}$ ini berbanding lurus dengan data dari BKKBN (2004) yang menunjukkan besarnya pernikahan di bawah usia 16 tahun di Indonesia, yaitu mencapai 25\% dari jumlah pernikahan yang ada. Bahkan di beberapa daerah persentasenya lebih besar, seperti di Jawa Timur (39,43\%), Kalimantan Selatan (35,48\%), Jambi (30,63\%), Jawa Barat (36\%), dan Jawa Tengah $(27,84 \%)$. $^{2}$ Pernikahan dini tersebut rata-rata dilakukan oleh komunitas santri, mengingat Kabupaten Malang adalah salah satu daerah tingkat II dengan jumlah pondok pesantren terbanyak di Indonesia, yakni mencapai 257 pondok pesantren. ${ }^{3}$ Kepala Badan Keluarga Berencana (KB) Kabupaten Malang sendiri, pada tanggal 9 November 2009, menyatakan bahwa pernikahan dini di Kabupaten Malang lebih banyak dilakukan oleh komunitas santri, sehingga untuk mengatasinya pihaknya perlu menggandeng Departemen Agama guna melakukan sosialisasi di pondok-pondok pesantren serta madrasah, baik tingkat tsanawiyah (MTs) maupun aliyah (MA). ${ }^{4}$

Namun, uniknya, kehidupan rumah tangga hasil pernikahan dini komunitas santri di Kabupaten Malang rata-rata tetap bertahan dan berlangsung secara relatif normal selayaknya rumah tangga pada umumnya. Perceraian dan-apalagi-perdagangan (trafficking) perempuan dan anak sama sekali tidak dijumpai dalam kehidupan rumah tangga mereka. Kenyataan ini berbanding lurus dengan data Pengadilan Agama Kabupaten Malang tentang faktor-faktor penyebab terjadinya perceraian tahun 2009 dan 2011. Pada tahun 2009, misalnya, dari total 3005 kasus perceraian, faktor penyebab paling dominan adalah karena rumah tangga kurang harmonis

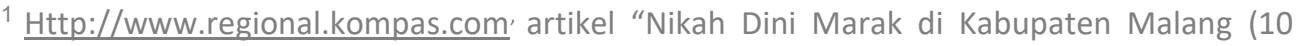
Februari 2009)" (akses tanggal 11 Mei 2011).

${ }^{2}$ Bappenas, Laporan Perkembangan Pencapaian Millennium Development Goals Indonesia 2007, Nopember 2007, halaman 37.

${ }^{3}$ Http://www.pendis.kemenag.go.id ' artikel "Direktori Pondok Pesantren 2008/2009: Prov. Jawa Timur Bagian I" (akses tanggal 11 Mei 2011).

${ }^{4} \mathrm{Http}: / /$ www.suaramerdeka.com, artikel "Tinggi, Pernikahan Usia Dini di Kabupaten Malang (9 Nopember 2009)" (akses tanggal 11 Mei 2011).
} 
(68,52\%), menyusul di bawahnya faktor karena sang suami meninggalkan kewajibannya (30,51\%). Peringkat yang sama juga terjadi pada tahun 2011, yakni rumah tangga tidak harmonis $(62,77 \%)$ dan sang suami meninggalkan kewajiban (30,69\%), menyusul di bawahnya gangguan pihak ketiga (2,66\%) dan masalah ekonomi $(1,75 \%)$. Hal terpenting dari data tersebut adalah bahwa pernikahan dinidisebut secara terpisah sebagai "kawin di bawah umur"-ternyata sama sekali tidak menyebabkan perceraian $(0,00 \%){ }^{5}$

Fenomena ini tentu berkebalikan dengan arus utama wacana pernikahan dini yang berkembang. Selama ini, pernikahan dini selalu diasumsikan sebagai salah satu pemicu terjadinya kekerasan dalam rumah tangga yang berujung kepada perceraian dan bahkan perdagangan (trafficking) perempuan. R. Valentina Sagala (2006), misalnya, menulis bahwa pernikahan dini adalah satu faktor yang mendorong remaja dan perempuan muda untuk terjerembab dalam prostitusi atau menjadi korban perdagangan (trafficking) perempuan. ${ }^{6}$ Pusat Kajian dan Perlindungan Anak (PKPA) di Nias (2007), sebagai contoh lain, melaporkan bahwa sepanjang 20052007 tercatat 109 kasus kekerasan terhadap perempuan, dengan dominasi kasus perkawinan usia dini. ${ }^{7}$ WCC Rifka Annisa (2008), sebagai contoh berikutnya, melansir data tentang kekerasan terhadap perempuan dalam rumah tangga. Dari data yang masuk sepanjang tahun 2000-2007, 4,8\% klien Kekerasan Terhadap Istri adalah mereka yang pernah menikah pada usia anak atau dibawah 18 tahun. Sedangkan klien yang pernah menikah pada usia 18-22 tahun sebesar 22,4\%.

${ }^{5}$ Http://www.pa-malangkab.go.id, artikel "Faktor-Faktor Penyebab Terjadinya Perceraian Tahun 2009" dan "Faktor-Faktor Penyebab Terjadinya Perceraian Tahun 2011" (akses tanggal 12 Mei 2011).

${ }^{6}$ R. Valentina Sagala, "Perdagangan Perempuan dan Anak dalam Pandangan Seorang Aktifis Perempuan", dalam Sulistyowati Erianto (ed.), Perempuan dan Hukum: Menuju Hukum yang Berperspektif Kesetaraan dan Keadilan, cetakan I (Jakarta: Yayasan Obor Indonesia, 2006), halaman 284.

${ }^{7}$ Http://www.langitperempuan.com, artikel “Dokurama 'Perempuan Nias' Angkat Nikah Dini Sebagai Kekerasan (23 Desember 2008)” (akses tanggal 11 Mei 2011). 
Paparan data tersebut selanjutnya berujung kepada kesimpulan bahwa pernikahan dini adalah salah satu penyebab terjadinya perceraian. ${ }^{8}$

Berkaca kepada fenomena kehidupan rumah tangga hasil pernikahan dini komunitas santri di Kabupaten Malang di atas, maka wacana yang mengaitkan pernikahan dini dengan kekerasan, perceraian, dan perdagangan perempuan serta menganggapnya sebagai tindakan kriminal sebenarnya mengandung dua sisi mata uang. Di satu sisi, wacana tersebut memang bertujuan untuk melindungi perempuan dari ragam bentuk eksploitasi yang merugikan kaum perempuan. Namun, di sisi lain, wacana tersebut memiliki ragam kelemahan yang cukup mendasar. Pertama, wacana tersebut lebih bertumpu kepada kekhawatiran daripada kenyataan empiris di lapangan. Alison Clarke-Stewart dan Joanne Barbara Koch (1983), misalnya, menyatakan bahwa remaja Amerika Serikat yang melakukan pernikahan dini justru mengalami perubahan gaya hidup dan perilaku yang lebih baik daripada remaja lain yang rata-rata terjebak dalam pola pergaulan seks bebas. ${ }^{9}$ Kedua, wacana tersebut bertumpu kepada hasil pengamatan yang tidak berimbang terhadap ragam faktor penyebab terjadinya pernikahan dini. Mengapa, sebab pernikahan dini yang rentan perceraian itu ternyata adalah pernikahan yang diakibatkan "kecelakaan" (hamil di luar nikah). Data yang disampaikan oleh Humas Pengadilan Agama Purworejo Jawa Tengah (2009), ${ }^{10}$ misalnya, mengindikasikan hal itu. Menurut E.B. Surbakti (2008), pernikahan dini akibat hamil di luar nikah menjadi rentan terhadap kecelakan, karena pernikahan dilakukan akibat keterpaksaan, bukan kesadaran dan kesiapan serta orientasi nikah yang kuat. ${ }^{11}$ Ketiga, wacana di atas cenderung mengabaikan kenyataan empiris di lapangan, yakni kehidupan rumah tangga hasil pernikahan

${ }^{8}$ WCC Rifka Annisa, "Dating Violence", makalah disampaikan dalam Diskusi Perempuan dan Kekerasan Berbasis Gender yang diadakan oleh LP. Amanah PPRU I Gondanglegi Malang pada tanggal 27 Mei 2008, halaman 1.

${ }^{9}$ Dikutip oleh: Mohammad Fauzil Adhim, Indahnya Pernikahan Dini, cetakan I (Jakarta: Gema Insani Press, 2002), halaman 21.

${ }^{10}$ Http://www.m.pikiran-rakyat.com, artikel "Hamil di Luar Nikah Picu Naiknya Kasus Pernikahan Dini (9 Juli 2009)” (akses tanggal 12 Mei 2011).

${ }^{11}$ E.B. Surbakti, Sudah Siapkah Menikah?: Panduan bagi Siapa Saja yang Sedang dalam Proses Menentukan Hal Penting dalam Hidup, cetakan I (Jakarta: PT Elex Media Komputindo, 2008), halaman 316. 
dini di sejumlah kawasan yang dapat berlangsung secara normal selayaknya rumah tangga pada umumnya.

Itulah sebabnya, mengamati kehidupan rumah tangga hasil pernikahan dini komunitas santri di Kabupaten Malang menjadi penting dilakukan. Mengapa, sebab pengamatan tersebut, terutama yang melibatkan pelaku pernikahan dini dari komunitas yang memiliki basis keagamaan yang kuat, bisa memperkaya perspektif wacana pernikahan dini itu sendiri; dalam arti tidak selalu bersifat teoretis-deduktif seperti yang terjadi selama ini, melainkan juga bisa bersifat empiris-induktif. Dari pengamatan tersebut, bisa diperoleh sebuah perspektif baru seputar pola relasi dan komitmen mempertahankan rumah tangga yang terbangun di kalangan komunitas santri pelaku pernikahan dini. Dengan kata lain, wacana pernikahan dinimeminjam ungkapan Rosalind Shaw (2006)_perlu melibatkan "perspektif bawah" (view from below), yakni realitas empiris kehidupan rumah tangga hasil pernikahan dini komunitas tertentu yang tetap bertahan dan berlangsung normal sebagaimana kehidupan rumah tangga pada umumnya, sebagai penyeimbang "perspektif atas" (view from above), yakni kajian teoretis-normatif-deduktif yang bertumpu kepada peraturan perundang-undangan. ${ }^{12}$

Bertitik tolak dari konteks di atas, maka penelitian ini berupaya mengungkap fenomena pernikahan dini yang dilakukan oleh perempuan santri, pola relasi rumah tangga yang terbangun di atasnya dan respon mereka terhadap ragam situasi relasional kerumahtanggaan yang terjadi. Penelitian ini bertujuan untuk mengetahui (1) pemahaman komunitas santri di Kabupaten Malang tentang pernikahan dini yang mereka lakukan; (2) pola relasi suami-istri dalam rumah tangga yang dibangun oleh komunitas santri pelaku pernikahan dini; dan (3) respon mereka terhadap ragam keadaan yang mereka hadapi untuk mempertahankan kehidupan rumah tangga. Dengan kata lain, tujuan akhir penelitian ini adalah untuk memberikan perspektif baru-atau "perspektif bawah" (view from below)-yang menyajikan realitas empiris seputar kehidupan rumah tangga hasil pernikahan dini

\footnotetext{
12 Rosalind Shaw, "Feminist Anthropology and the Gendering of Religious Studies", dalam Russel T. McCutcheon (ed.), The Insider/Outsider Problem in the Study of Religion: A Reader, cetakan I (London dan New York: Casell, 1999), halaman 106-108.
} 
komunitas santri yang bukan saja tetap bertahan dan berlangsung dengan normal selayaknya kehidupan rumah tangga pada umumnya, melainkan juga jauh dari isu perceraian dan perdagangan (trafficking) perempuan dan anak sebagaimana dilekatkan kepada pernikahan dini selama ini. Perspektif baru tersebut sekurangkurangnya bisa menjadi pembanding terhadap "perspektif atas" (view from above) yang dominan dalam wacana pernikahan dini selama ini.

\section{KOMUNITAS SANTRI DAN PERNIKAHAN DINI}

\subsection{Pernikahan Dini}

Dalam tradisi fiqih Islam klasik, pernikahan dini biasanya disebut dengan term "pernikahan anak kecil yang belum berusia baligh" (nikāh al-shaghīr). Itu pun bukan dalam konteks sah atau tidaknya, melainkan teknis operasional pelaksanaannya. Mengapa, sebab mayoritas ulama ahli fiqih pernikahan dini adalah sah hukumnya, karena Rasulullah saw. sendiri pernah melakukannya-menikahi 'Ā'isyah r.a. yang masih berusia 6 tahun. Hanya Ibn Syibrimah, Abū Bakr al-Ashamm, 'Utsmān alBattī, dan Ibn Hazm saja yang menyatakan tidak sah. ${ }^{13}$

Pernikahan dini baru mencuat ke permukaan dalam wacana hukum Islam di era modern, tepatnya di saat mulai bermunculan ragam gugatan dari kalangan aktivis feminisme dan kesetaraan gender. Dalam wacana hukum Islam era modern, pernikahan dini biasanya disebut dengan "al-zawāj al-mubakkir", sementara tolok ukurnya adalah usia balig yang ditandai dengan gejala fisik berupa menstruasi. Dengan demikian, tolok ukur pernikahan dini menjadi relatif, sebanding dengan

${ }^{13}$ Wahbah al-Zuhaylī, al-Fiqh al-Islāmī wa Adillatuh, juz VII, cetakan II (Beirut: Dār al-Fikr, 1985), halaman 179; 
relativitas usia balig perempuan itu sendiri yang sangat bergantung kepada kondisi fisik personal dan realitas sosial-budaya. ${ }^{14}$

Batasan pernikahan dini kemudian didefinisikan berdasarkan usia, seiring dengan bermunculannya regulasi perundang-undangan, baik yang ditetapkan oleh organisasi berskala nasional maupun institusi negara. Namun, ketentuan batas usia yang ditetapkan ternyata sangat beragam, tergantung kepada argumentasi filosofis dan kondisi sosial-budaya yang melatarbelakangi masing-masing institusi. Meskipun UNICEF-badan PBB untuk anak-anak-sudah menetapkan batas usia 18 tahun baik untuk laki-laki maupun perempuan, ${ }^{15}$ namun regulasi yang diberlakukan oleh berbagai negara di berbagai penjuru dunia ternyata cukup beragam-rata-rata berkisar antara 15-21 tahun dengan keunikan regulasi antara laki-laki dan perempuan, bergantung kepada realitas sosial-budaya dan kepentingan politik yang melatarbelakanginya. ${ }^{\mathbf{1 6}}$

Untuk konteks Indonesia, regulasi perundang-undangan seputar batas usia pernikahan masih kontradiktif dan simpang-siur. Di satu pihak, Undang-undang Nomor 1 Tahun 1974 tentang Pernikahan Pasal 7 Ayat 1 mengatur bahwa usia 19 tahun untuk lak-laki dan usia 16 tahun untuk perempuan adalah batasan minimal usia perkawinan-seseorang di bawah usia itu tetap bisa menikah jika mendapat dispensasi dari hakim pengadilan (Pasal 7 Ayat 2). ${ }^{17}$ Namun, di pihak lain, Undangundang Nomor 23 Tahun 2002 tentang Perlindungan Anak Pasal 26 Ayat 1 ternyata menegaskan bahwa orang tua wajib mencegah pernikahan pada usia anak-anak, yakni usia di bawah 18 tahun seperti ditegaskan oleh Pasal 1 Ayat $2 .{ }^{\mathbf{1 8}}$ Kontradiksi

\footnotetext{
${ }^{14}$ Mushthafā al-Qudhāt, "al-Tabkīr fĩ al-Zawāj wa al-Ātsār al-Mutarattibah 'alayh", Majallah Jāmi'ah Dimisyq li al-'Ulūm al-lqtishādiyyah wa al-Qānūniyyah, edisi 26, nomor I, tahun 2010, halaman 446.

${ }^{15} \mathrm{Http}$ ://www.unicef.org, artikel “Child marriage” (akses tanggal 13 Mei 2011).

16 Tentang regulasi usia perkawinan berbagai negara di dunia, lihat: Tahir Mahmood, Personal Law in Islamic Countires: History, Text and Comparative Analysis (New Delhi: Academy of Law and Religion, 1987), halaman 269-270; UNICEF, Child Marriage and the Law: Legislative Reform Initiative Paper Series, Februari 2008.

17 Undang-undang Nomor 1 Tahun 1974 tentang Perkawinan; Lembaran Negara Republik Indonesia Tahun 1974 Nomor 1, Pasal 7 Ayat 1 dan 2.

18 Undang-undang Nomor 23 Tahun 2002 tentang Perlindungan Anak; Lembaran Negara Republik Indonesia Tahun 2002 Nomor 109, Pasal 1 Ayat 1 dan Pasal 26 Ayat 1.
} 
regulasi di atas sudah pasti berimbas kepada kaburnya batasan definitif untuk mengidentifikasi kasus pernikahan dini; antara 18 dan 19 tahun untuk laki-laki, dan antara 16 dan 18 tahun untuk perempuan.

\subsection{Komunitas Santri}

Terdapat beberapa spekulasi terkait asal-usul kata "santri". Nurcholish Madjid melansir dua pendapat tentang asal-usul kata "santri", yaitu: (1) santri berasal dari kata "sastri" (Bahasa Sanskerta) yang memiliki arti "melek huruf", dan (2) kata "santri" sesungguhnya berasal dari kata "cantrik" (Bahasa Jawa) yang berarti "seseorang yang selalu mengikuti gurunya ke manapun dia pergi ataupun menetap". ${ }^{19}$ Sementara Zamakhsyari Dhofir (1982) menyatakan bahwa selain berasal dari kata "sastri" (Bahasa Sansekerta), kata "santri" juga bisa berasal dari Bahasa Tamil yang berarti "guru mengaji”. 20

Namun, perbedaan pendapat tentang asal-usul kata tersebut sama sekali tidak menafikan fakta bahwa santri tidak lepas dari pesantren, baik secara langsung ataupun tidak langsung. Hal ini terlihat dari ragam definisi santri yang dikemukakan oleh para ahli pemerhati dunia pesantren. Zamakhsyari Dhofir (1982), misalnya, mendefinisikan santri sebagai murid-murid yang tinggal di dalam pesantren untuk mengikuti pelajaran kitab-kitab kuning atau kitab-kitab Islam klasik, baik yang menetap di dalam lingkungan pesantren (santri mukim) maupun yang tidak (santri kalong). ${ }^{21}$ Definisi di atas tentu berbeda dengan yang dibuat oleh Clifford Geertz dua puluh dua tahun sebelumnya (1960), yaitu bahwa santri adalah komunitasbiasanya termanifestasi sebagai para pedagang di perkotaan-yang melaksanakan ajaran Islam dengan cermat dan teratur, beribadah di masjid, berpuasa, dan menunaikan haji ke Mekkah. Di pedesaan, juga terdapat komunitas santri yang kuat, seringkali dipimpin oleh petani kaya yang telah naik haji dan setelah kembali

19 Nurcholish Madjid, Bilik-bilik Pesantren: Sebuah Potret Perjalanan, cetakan I (Jakarta: Paramadina, 1997), halaman 19.

20 Zamakhsyari Dhofier, Tradisi Pesantren Studi tentang Pandangan Hidup Kyai, cetakan I (Jakarta, LP3ES, 1982), halaman 18.

${ }^{21}$ Ibid., halaman 51. 
mendirikan pesantren. ${ }^{22}$ Definisi dari Geertz kemudian dicoba untuk disederhanakan oleh Munir Mulkhan (1994). Menurutnya, kata "santri" dalam khasanah kehidupan bangsa dan masyarakat Islam di Indonesia memiliki dua makna, yaitu (1) makna sempit, yaitu sekelompok peserta sebuah pendidikan pesantren atau pondok, dan (2) makna luas yang menunjuk kepada akar budaya sekelompok pemeluk Islam, yaitu bagian penduduk Jawa yang memeluk Islam secara benar-benar, bersembahyang, pergi ke Masjid, dan melakukan berbagai aktifitas lainnya. ${ }^{23}$

Definisi santri dari Geertz yang disederhanakan oleh Munir Mulkhan di atas selanjutnya menjadi sebuah definisi standar. Sejumlah penelitian dan kajian seputar tema-tema yang berhubungan dengan kehidupan santri rata-rata mengacu kepada definisi yang kurang-lebih sama dengan definisi di atas. Jazim Hamidi dkk. (2007), misalnya, meneliti tentang persepsi masyarakat santri di Jawa Timur tentang bank syari'ah. Masyarakat santri, menurut penelitian tim peneliti dari Universitas Merdeka Malang ini, meliputi (1) kiai, ulama, dan ustadz, (2) santri pondok pesantren, yaitu siswa yang belajar di pondok pesantren, baik santri mukim maupun santri kalong, (3) alumni pondok pesantren, yakni orang yang sudah tamat dari atau pernah belajar di pesantren, dan (4) masyarakat sekitar pesantren yang mengadopsi positif budaya pesantren. ${ }^{24}$ Mudjahirin Thohir (2009), guru besar antropologi dari Universitas Diponegoro Semarang, juga menggunakan definisi yang sama. Menurutnya, yang dimaksud dengan komunitas santri adalah sejumlah penduduk yang tinggal secara menetap di suatu daerah dalam waktu yang tidak dibatasi, di mana cara hidup mereka menekankan kepada aturan-aturan yang bersumber dari ajaran agama, sebagai pedoman baik dalam tata peribadatan maupun tata pergaulan antar sesama, bahkan untuk merasa, berfikir, dan menentukan keputusan.

22 Clifford Geertz, The Religion of Java (Chicago: University of Chicago Press, 1960), halaman 5, 215 dan 222.

${ }^{23}$ Abdul Munir Mulkhan, Runtuhnya Mitos Politik Santri: Strategi Kebudayaan Islam, cetakan I (Yogyakarta: Sipress, 1994), halaman 1.

24 Jazim Hamidi dkk., "Persepsi dan Sikap Masyarakat Santri Jawa Timur terhadap Bank Sari'ah", Jurnal Keuangan dan Perbankan, Universitas Merdeka Malang, Tahun XI, Nomor 3, September 2007. 
Pengetahuan tentang hal itu biasanya mereka peroleh dari lembaga-lembaga pendidikan yang disebut dengan pesantren di samping majelis-majelis pengajian. ${ }^{25}$

\subsection{Pola Relasi Rumah Tangga}

Letha D. Scanzoni dan John H. Scanzoni (1981) melansir empat tipe relasi suamiistri dalam keluarga. Pertama adalah pola owner property, yaitu ketika suami berposisi sebagai satu-satunya pencari nafkah bagi keluarga serta sebagai "penguasa" yang memiliki secara penuh kehidupan istrinya. Tugas utama istri adalah mengabdi dan tunduk secara ekonomi kepada suami serta mengurus keluarga. Kedua adalah pola head complement, yaitu pola di mana istri berposisi sebagai pelengkap suami. Meskipun relatif masih sama dengan pola owner property, namun suami dalam pola kedua ini sudah menghargai dan membantu pekerjaan istri. Ketiga adalah pola senior-junior partner, yaitu ketika posisi istri mulai meningkat. Dia mempunyai penghasilan sendiri sehingga tidak tergantung sepenuhnya kepada suami. Walaupun demikian, pencari nafkah utama tetap suami sehingga mempunyai kekuasaan lebih dibanding istri. Keempat adalah pola equal partner, yaitu ketika posisi dan peluang suami-istri setara, meskipun tugas dan peran yang dipilih berbeda. Dalam pola perkawinan seperti ini, perkembangan individu sebagai pribadi sangat diperhatikan. ${ }^{\mathbf{2 6}}$ Namun, pola-pola relasi rumah tangga di atas sesungguhnya tidak bergerak statis. Pola relasi suami-istri dalam suatu keluarga selalu mengalami perubahan, sesuai dengan perubahan sosial-budaya yang mengitarinya. Sebagaimana dijelaskan oleh Burgess dan Locke (1960) dan Duvall (1967), sejarah menunjukkan bahwa pola relasi suami-istri senantiasa berubah dan bergerak dari pola institusional yang bersifat otoriter menuju pola pola companionship yang

25 Mudjahirin Thohir, "Makna Khoul bagi Komunitas Santri (6 Maret 2009)", http://staff.undip.ac.id (akses tangga; 13 Mei 2011).

${ }^{26}$ Dikutip oleh: Evelyn Suleeman, "Hubungan-hubungan dalam Keluarga”, dalam T.O. Ihromi (ed.), Bunga Rampai Sosiologi Keluarga, cetakan I (Jakarta: Yayasan Obor Indonesia, 1999), halaman 100-105. 
bersifat demokratis-egaliter. Perubahan tersebut bisa terjadi sebagai akibat dari perubahan sosial yang selalu bergulir dengan cepat dari waktu ke waktu. ${ }^{27}$

Perubahan dari pola institusional menuju pola companionship juga terjadi pada relasi suami-istri rumah tangga yang dibangun oleh komunitas santri. Selama ini, pola relasi rumah tangga komunitas santri dianggap lekat dengan pola institusional atau pola owner propherty dan head-complement. Tradisi keberagamaan dan keilmuan yang banyak bersumber dari kitab-kitab klasik yang cenderung kental budaya patriarkalnya diduga kuat menjadi salah satu penyebabnya. Salah satu kitab klasik yang paling menonjol sebagai rujukan komunitas santri terkait dengan relasi

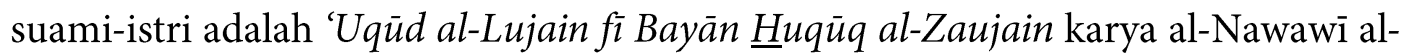
Jāwī al-Bantanī (1813-1897) yang populer dengan nama Nawawi Banten. Kitab ini menegaskan bahwa selain berhak untuk, misalnya, memperoleh mahar, nafkah, pendidikan, dan perlakuan yang baik, seorang istri juga berkewajiban untuk mematuhi suaminya dalam semua aspek kehidupan rumah tangga. Ketaatan seorang istri kepada suaminya bisa disamakan seperti ketaatan anak kepada orang tuanya atau bahkan "tawanan" kepada majikannya.. ${ }^{28}$

Seiring dengan perkembangan dan perubahan sosial dan budaya, tradisi keilmuan dan keberagamaan komunitas pesantren pun mengalami perubahan pula. Bermunculan ragam gagasan-termasuk dari kalangan komunitas santri sendiriyang menyuarakan kesetaraan gender, inklusif di dalamnya relasi suami-istri. Sinta Nuriyah Wahid, misalnya, mempelopori Forum Kajian Kitab Kuning (FK3) dalam mengkaji kitab 'Uqūd al-Lujayn fì Bayān $\underline{H} u q u \bar{q}$ al-Zawjayn karya al-Nawawī alJāwī al-Bantanī serta mempublikasikan hasil diskusi menjadi sebuah buku berjudul Wajah Baru Relasi Suami Istri: Telaah Kitab 'Uqūd al-Lujjayn (2001). Buku tersebut menyimpulkan bahwa kitab tersebut mengandung masalah terkait dengan penggunaan hadits sebagai sumber. Mengapa, sebab dari sekitar 120-an hadits yang

27 Ibid., halaman 100; Mary Ann Lamanna dan Agnes Riedmann, Marriages and Families: Making Choices in a Diverse Society, cetakan X (California: Wadsworth Publishing, 2009), halaman 3.

${ }^{28}$ Al-Nawawī al-Jāwī al-Bantanī, 'Uqūd al-Lujayn fĩ Bayān Huqūq al-Zawjayn (Semarang: Usaha Keluarga, t.t.), halaman 8. 
digunakan, 26 hadits diantaranya berkualitas lemah ( $\left.d l a^{`}{ }^{`} f\right)$ dan 35 hadits berstatus hadits palsu (maudlū $){ }^{29}$ Sejumlah ulama NU, seperti Husein Muhammad dan Mustofa Bisri, juga menyampaikan kesimpulan yang senada serta menyarankan agar kitab tersebut diteliti ulang secara kritis karena isinya yang kental dengan budaya patriarki dan penggunaan sumber haditsnya yang problematis. ${ }^{30}$ Berbagai gagasan baru tersebut berbanding lurus dengan semakin tingginya tingkat kesadaan komunitas santri tentang kesetaraan gender dalam kehidupan domestik dan publik dewasa ini. Hal ini dibuktikan oleh, misalnya, Zuni Afifah, melalui karya skripsinya "Pandangan Santri Nurul Ummah terhadap Kekerasan dalam Rumah Tangga menurut UU No. 23 Tahun 2004" (2010), yang menyimpulkan bahwa komunitas santri sudah mulai akrab dengan wacana-wacana keadilan gender. ${ }^{31}$

Oleh sebab itu, untuk mengamati pola relasi suami-istri yang terbangun dalam sebuah rumah tangga, termasuk hasil pernikahan dini komunitas santri, teori marital power, yaitu konsep pembagian peran dan kekuasaan dalam sebuah keluarga, yang dikembangkan oleh Ronald E. Cromwel dan David H. Olson (1975) relevan untuk dipakai sebagai pisau analisis. Konsep tersebut meliputi tiga aspek, yaitu (1) power bases, yaitu sumber asal kekuasaan, seperti sumber ekonomi, afeksi, dan kognisi-utamanya berkaitan dengan siapa yang berhak memiliki kendali dalam rumah tangga, (2) power processes, yaitu cara berinteraksi dan berkomunikasi antarpasangan, meliputi persepsi di saat berkomunikasi, pengalaman pascakomunikasi, dan sikap yang diambil di saat dan setelah berkonflik, dan (3) power outcomes, yaitu berkaitan dengan siapa yang pada akhirnya menjadi pengambil keputusan dalam proses negosiasi antara pasangan. ${ }^{32}$ Teori marital

29 Forum Kajian Kitab Kuning (FK3), Wajah Baru Relasi Suami Istri: Telaah Kitab 'Uqūd alLujjayn, cetakan I (Yogyakarta: LKiS, 2001).

30 Siany Indria Liestyasari, "Konstruksi Sosial Kultural Poligini dalam Pesantren", Jurnal Sosiologi DILEMA, Universitas Sebelas Maret Surakarta, Vol. 18 No. 2 Th. 2006, halaman 137.

${ }^{31}$ Zuni Afifah, "Pandangan Santri Nurul Ummah terhadap Kekerasan dalam Rumah Tangga menurut UU No. 23 Tahun 2004”, Skripsi (Yogyakarta: UIN Sunan Kalijaga, 2010).

32 Dikutip oleh: Julia C. Babcock dkk., "Power and Violence: The Relation Between Communication Patterns, Power Discrepancies, and Domestic Violence", Journal of Consulting and Clinical Psychology, Vol. 61, No. 1, Tahun 1993, halaman 40-50. 
power tersebut selanjutnya diterjemahkan menjadi "roda kesetaraan" (wheel of equality) dengan delapan indikator untuk menentukan apakah relasi dalam sebuah rumah tangga sudah setara ataukah tidak. Delapan indikator tersebut adalah: (1) non-threatening behavior, yaitu sikap tidak mengancam baik dalam perkataan maupun perbuatan, sehingga pasangan sama-sama merasa nyaman untuk berekspresi dan bertindak, (2) respect, yaitu bersikap menghargai pandangan pasangan, (3) trust anda Support, yakni sikap percaya dan mendukung cita-cita hidup, hak-hak, pendapat dan aktifitas pasangan, (4) honesty and Accountability, yakni kejujuran dan keterbukaan terhadap apa yang telah terjadi pada pasangan, (5) responsible parenting, yaitu menjadi orang tua yang bertanggung jawab serta menjadi teladan anti kekerasan bagi anak-anaknya, (7) shared responsibility, yaitu pembagian peran dan tanggung jawab secara fair atas dasar kesepakatan bersama, (8) economic partnership, yaitu kemitraan ekonomi melalui keputusan bersama dalam hal keuangan, baik perencanaan, pemasukan maupun pengeluaran, dan (9) negotiation and fairness, yaitu negosiasi dalam penyelesaian konflik yang terjadi secara fair, jujur dan terbuka.

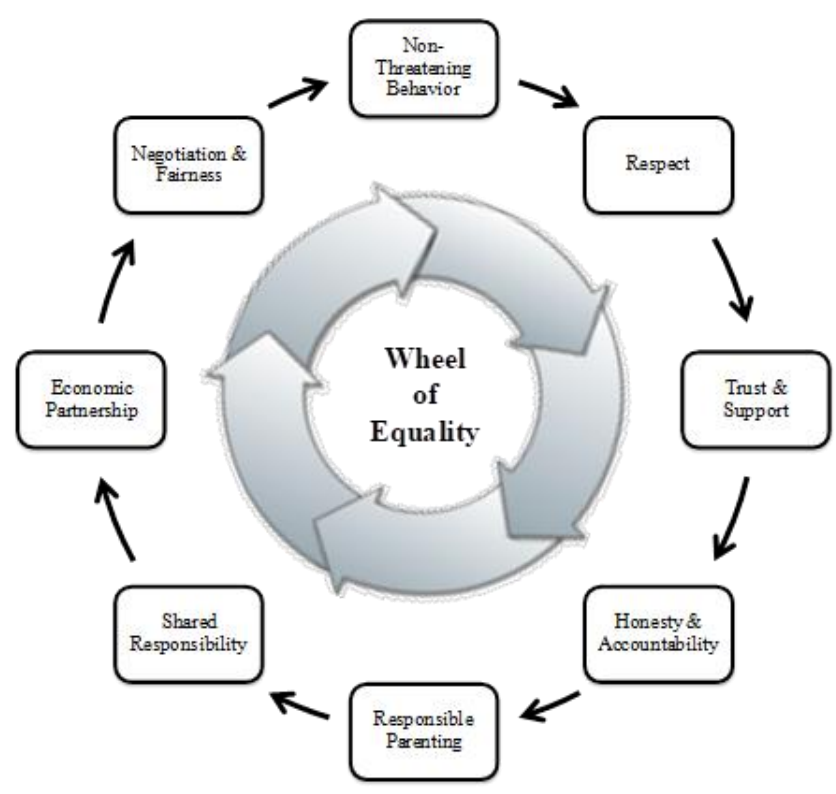

Gambar 1. Roda Kesetaraan Relasi Suami-Istri ${ }^{33}$ 


\section{METODE PENELITIAN}

Penelitian ini menggunakan pendekatan fenomenologis yang bertujuan untuk memahami, mendeskripsikan dan menginterpretasi makna dan esensi dari pengalaman hidup seseorang atau suatu komunitas berdasarkan kesadaran, ungkapan dan pemahaman mereka sendiri serta interpretasi dan pemaknaan dari peneliti. $^{34}$ Selain karena belakangan ini dianggap sebagai salah satu pendekatan alternatif yang cukup penting dalam penelitian kualitatif, ${ }^{35}$ pendekatan fenomenologis ini cukup relevan untuk makna dan esensi dari fenomena pernikahan dini yang dilakukan oleh komunitas santri di Malang, yakni pemahaman mereka tentang pernikahan dini serta pengalaman mereka dalam membangun dan mempertahankan rumah tangga hasil pernikahan dini.

Sudah pasti, dengan pendekatan fenomenologis, penelitian ini berusaha mendekati fenomena pernikahan dini komunitas santri dengan pikiran polos tanpa asumsi, praduga ataupun konsep. Pandangan, gagasan, asumsi ataupun konsep yang telah dimiliki sebelumnya harus dikurung sementara (bracketing atau époché dalam istilah Husserl) seraya membiarkan informan mengungkapkan pemahaman dan pengalamannya. ${ }^{36}$ Dengan cara itu, penelitian ini akan bisa melakukan interpretasi secara akurat dan mengungkap makna terdalam dari fenomena pernikahan dini komunitas santri, serta menghasilkan nuansa dan teori baru yang khusus dan unik.

${ }^{34}$ Catherine Adams dan Max van Manen, "Phenomenology", dalam Lisa M. Given (ed.), The Sage Encyclopedia of Qualitative Research Methods, cetakan I (California: SAGE Publications, Inc., 2008), halaman 614.

$35 \mathrm{lbid}$.

${ }^{36}$ Ibid., halaman 617; John W. Creswell, Qualitative Inquiry and Research Design: Choosing among Five Traditins, cetakan I California: SAGE Publications, Inc., 1998), halaman 52. 


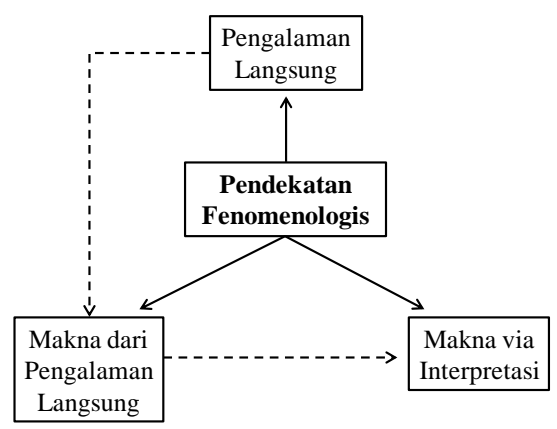

Gambar 2. Pendekatan Fenomenologis ${ }^{37}$

Penelitian ini mengambil lokasi Kecamatan Gondanglegi yang terletak sekitar $20 \mathrm{~km}$ ke arah selatan dari Kota Malang, terutama Desa Ganjaran, Putat Lor, Putukrejo, Sukosari, Bulupitu; lima desa yang berdekatan satu sama lain. Penentuan lima desa ini didasari oleh tiga pertimbangan. Pertama, Kecamatan Gondanglegi dikenal sebagai kawasan santri, karena memiliki lebih dari 65 pondok pesantren yang tersebar di sejumlah desa. 60\% lebih di antaranya beraada di lima desa tersebut; Ganjaran (20 lembaga), Putat Lor (7), Sukosari (7), Putukrejo (5), dan Bulupitu (5). ${ }^{38}$ Jumlah ini masih belum menghitung madrasah diniyah dan TPQ yang rata-rata berafiliasi kepada pondok pesantren dan dikelola oleh komunitas santri. Kedua, lima desa di atas didominasi oleh etnis Madura yang telah menetap sebagai warga pribumi secara turun-temurun. Meski bahasa dan kehidupan sosial khas Madura sangat kental, masyarakat di kawasan ini dalam segala aspek kehidupan telah berbaur erat dengan etnis Jawa. ${ }^{39}$ Ketiga, rumah tangga hasil pernikahan dini terhitung cukup banyak dan relatif mudah dijumpai, baik yang baru saja dijalin maupun yang sudah berketurunan. Beberapa di antaranya bahkan masih dalam satu rumpun keluarga besar (extended family) yang sama.

Sudah tentu, tidak semua keluarga komunitas santri hasil pernikahan dini di lima desa di atas dijadikan sebagai informan dalam penelitian ini, mengingat jumlahnya yang relatif banyak. Penelitian ini hanya menggunakan 20 keluarga saja sebagai

37 J.R. Raco, Metode Penelitian Kualitatif: Jenis, Karakteristik dan Keunggulannya, cetakan I (Jakarta: Grasindo, 2010), halaman 84.

${ }^{38} \mathrm{Http}$ ://pendis.kemenag.go.id artikel "Direktori Pondok Pesantren 2008/2009: Prov. Jawa Timur Bagian I" (akses tanggal 11 Mei 2011).

${ }^{39} \mathrm{Http}$ ://gondanglegi.malangkab.go.id' artikel “Data Penduduk"(akses tanggal 11 Mei 2011). 
informan awal, yakni tujuh di Desa Ganjaran, empat di Desa Putukrejo, empat di Desa Bulupitu, tiga di Desa Putat Lor, dan tiga Desa Sukosari. 20 keluarga tersebut betul-betul merepresentasikan komunitas santri, karena memiliki ragam indikasi berikut: (1) keluarga pengasuh pondok pesantren, (2) pernah nyantri (belajar dan tinggal) di pondok pesantren, (3) tinggal di sekitar pondok pesantren, dan (4) ratarata terlibat aktif dalam kegiatan yang dilaksanakan oleh pondok pesantren.

Namun, dalam hal pemilihan informan, penelitian ini tetap mengikuti pola bola salju (snow ball sampling), untuk membuka peluang yang seluas-luasnya bagi pihakpihak lain yang bisa memperkaya informasi serta memiliki hubungan kultural dengan informan awal, seperti orang tua, guru, teman, dan sebagainya. Pola ini dinilai penting, agar penelitian ini bisa mencapai apa yang disarankan oleh David L. Morgan (2006), yaitu bahwa semakin berwarna sebuah sampel maka semakin kaya pula segmen data yang bisa diperoleh.

Pengumpulan data dalam penelitian ini bertumpu pada teknik wawancara, baik dalam bentuk wawancara terstrukrur maupun wawancara mendalam (in-depth interview), sebab wawancara adalah teknik yang paling penting dalam sebuah penelitian etnografis. ${ }^{40}$ Wawancara terstruktur dilakukan dalam rangka memperoleh informasi yang sifatnya mendasar mengenai karakteristik informan, seperti umur, pendidikan, status sosial dan lain-lain. Untuk memperkaya data hasil wawancara, pengamatan terlibat (participant observation) juga dilakukan. Dalam hal ini, peneliti berbaur dan berinteraksi secara alamiah dengan informan--, seraya mengamati perilaku gestural mereka, baik di saat menjawab pertanyaan maupun melakukan aktivitas keseharian yang berhubungan dengan rumah tangga mereka. Kegiatan pengamatan pada dasarnya dilaksanakan secara simultan dengan wawancara. Kadang-kadang hasil dari pengamatan memunculkan ragam data baru yang perlu ditindaklanjuti dengan wawancara.

Analisis data dalam penelitian ini menggunakan model analisis interaktif yang diperkenalkan oleh Matthew B. Miles dan Michael Huberman (1994). Model analisis 
tersebut meliputi empat komponen yang saling berkaitan satu sama lain, yaitu (1) pengumpulan data (data collection), (2) penyederhanaan data (data reduction), (3) pemaparan data (data display), dan (4) penarikan dan pengujian simpulan (conclusion drawing and verification). Mengacu kepada model interaktif, analisis data tidak saja dilakukan setelah pengumpulan data, tetapi juga secara simultan serta bertali-temali dengan proses penggalian data. Dengan demikian analisis data dilakukan secara berulang-ulang (cyclical).$^{41}$

Namun, untuk dapat mengungkap akar-akar tradisi pernikahan dini komunitas santri di Kabupaten Malang, maka penelitian ini juga melibatkan teknik analisis yang dianjurkan oleh James P. Spradley (1980). Teknik analisis tersebut meliputi: (1) analisis ranah (domain analysis), yakni upaya memperoleh gambaran umum tentang data untuk menjawab fokus penelitian, (2) analisis taksonomik (taxonomic analysis), yakni upaya memahami domain-domain tertentu sesuai fokus masalah atau sasaran penelitian, (3) analisis komponensial (componential analysis), yakni upaya mengkontraskan antardomain yang diperoleh untuk dibuat kategorisasi yang relevan, dan (4) analisis tema budaya (discovering cultural themes), yakni upaya memahami gejala-gejala yang khas dari analisis sebelumnya, mengumpulkan sekian banyak tema, fokus budaya, nilai, dan simbol-simbol budaya yang ada dalam setiap domain, dan menemukan hubungan-hubungan yang terdapat pada domain yang dianalisis, sehingga akan membentuk satu kesatuan yang holistik. ${ }^{42}$

\section{AKAR TRADISI PERNIKAHAN DINI KOMUNITAS SANTRI KABUPATEN MALANG}

Secara umum, tradisi pernikahan dini komunitas santri di Kabupaten Malang berakar pada (1) pemahaman keagamaan, (2) budaya, dan (3) ekonomi. Namun,

${ }^{41}$ Matthew B. Miles dan Michael Huberman, Qualitative Data Analysis: An Expanded Sourcebook, cetakan II (California: SAGE Publications Inc., 1994), halaman 9-11.

42 Dikutip oleh Mudjia Rahardjo, “Analisis Data dalam Penelitian Kualitatif (11 Juni 2010)", http://www.mudjiarahardjo.com (akses tanggal 13 Mei 2011). 
dari tiga domain tersebut, latar pemahaman keagamaan dan budaya jauh lebih dominan dari pada latar ekonomi.

Dalam kehidupan pesantren, doktrin agama dan tradisi keberagamaan terhitung sangat kuat dan terasa dalam denyut aktifitas sehari-harinya. Pemahaman Islam yang khas ditransmisikan dan diaplikasikan secara konsisten di lingkungan pesantren. Hal ini terutama tergambar dari kriteria 'alim yang tidak hanya direpresentasikan dari kecerdasan intelektualnya semata, tapi harus dibarengi dengan kesalehan atau kesempurnaan akhlaq sosialnya.

Pada umumnya, dalam tradisi masyarakat pesantren, terutama di daerah kecamatan Gondanglegi, hubungan laki-laki dan perempuan sangat dijaga. Laki-laki dan perempuan yang menghindari hubungan terlalu dekat dengan lawan jenisnya menjadi salah satu criteria terjaganya muru'ah-nya. Hal ini juga berimbas pada hubungan pra-perkawinan (pertunangan). Dalam hubungan pertunangan, antara calon suamiistri tidak diperbolehkan untuk menjalin komunikasi yang intensif meskipun untuk tujuan pengenalan secara lebih dekat. Jika keduanya ingin melakukan pengenalan tersebut maka salah satu solusinya adalah dengan melakukan pernikahan sirr. Tuturan Lt berikut ini menunjukkan hal itu:
"Kami bertunangan selama sekitar 4 bulan. Tapi ternyata ketika acara lamaran, nenek memutuskan menikahkan kami karena calon suami sering mengunjungi saya. Pada awalnya, ketika calon suami meminta saya ke orang tua, saya mau dengan target menikah beberapa tahun lagi. Tapi ternyata rencana berubah dengan mendadak." (Lt)

Tuturan yang senada juga disampaikan oleh Lm:
"Lulus Mts saya mondok di Kediri dan 1,5 tahun kemudian, kami dinikahkan secara sirri. Waktu itu saya berumur 17 tahun dan suami 22 tahun. Waktu pernikahan sirri itu saya juga tidak tahu, karena saya sedang di pondok dan akad nikah itu dilangsungkan di Malang di rumah seorang Habib. Saya tahu dinikahkan ketika mertua ke pondok bersama suami dan saya disuruh salaman. Saya tidak pernah tanya ke orang tua kenapa saya dinikahkan secara sirri. Kata suami, kami disirri agar bisa pendekatan secara halal, apalagi kami belajar di pondok yang sama. Sebelum 
nikah, kalau dipanggil calon suami dan calon mertua saya tidak mau menemui." (Lm)

Budaya, atau dalam bahasa Inggris culture, menurut Taylor yang dikutip oleh Alfian, adalah suatu pengetahuan yang menyeluruh dan kompleks yang tercakup dalam pengetahuan (knowledge) kepercayaan, seni, hukum, moral, adat/tradisi, kapabilitas, dan kebiasaan-kebiasaan lainnya yang dimiliki seseorang sebagai anggota suatu masyarakat. Dari pengertian ini bisa dipahami bahwa budaya bisa juga dimaknai sebagai system nilai yang memberikan kepada seseorang suatu carapandang untuk menterjemahkan dan menilai terhadap apa yang riil (apa yang tidak riil) yang memungkinkan dia membedakan dan memilih apa yang betul dan apa yang salah.

Faktor ketakutan menjadi perawan tua menjadi salah satu alasan kenapa informan melakukan pernikahan dini. $\mathrm{Hb}$ (32 th) mengatakan:

"Saya dipaksa oleh orang tua saya. Saya tidak tahu pasti kenapa orang tua saya menikahkan saya di usia tersebut. Kayaknya sih, alasan apalagi kalau bukan takut saya ndak laku nantinya." ( $\mathrm{Hb})$

Bagi perempuan pesantren kebebasan memilih pasangan sulit diperoleh. Hal ini semakin didukung oleh pengalaman sebagian mereka yang memilih pasangan sendiri dan ternyata tidak sesuai dengan nilai baik-buruk dalam masyarakat pesantren. Im (28 th.) mengatakan:

"Saya ditunangkan sejak kelas dua SMA. Saya sebenarnya tidak mau, tapi dipaksa. Kata orang tua, "mau cari suami sendiri? Nanti kayak kakakmu tuh... dapat orang yang tidak genah. Calon suamimu tuh orang bagus, dari keluarga kiai." (Im)

Meskipun minoritas, faktor kesulitan ekonomi juga menjadi salah satu alasan menikahkan anak dalam usia dini di kalangan masyarakat pesantren. Kh bertutur:

“Orang tua menikahkan saya kayaknya biar cepat mentas.” (Kh).

Orang tua Kh tidak memiliki penghasilan yang cukup, sementara jumlah anak yang harus dinafkahi cukup banyak yaitu 5 orang. Ayahnya sudah berusia lanjut dan hanya bekerja menjadi penembel ban sepeda yang bocor, sementara ibunya seorang 
tukang pijat panggil yang tidak setiap hari mendapat pasien. Tiga adiknya juga menikah pada usia muda.

Sementara itu, perilaku pernikahan dini perempuan santri yang menjadi subyek penelitian ini bisa dipilah dari dua perspektif yang saling berkaitan, yaitu (1) perspektif partisipasi perempuan dalam memilih pasangan dan (2) perspektif legalitas pernikahan. Dari perspektif partisipasi, mayoritas informan penelitian ini melakukan pernikahan karena kemauan keluarganya. Hanya sedikit dari mereka yang melaksanakan pernikahan dini atas kemauan sendiri.

Mayoritas informan yang melakukan pernikahan dini kareta kehendak keluarganya memiliki dua sikap yang berbeda, ada yang merasa terpaksa namun juga ada yang merasa suka-rela. Lt (34 th.), misalnya, menjalani masa awal pernikahannya secara setengah hati:

"Pada awalnya ketika calon suami meminta saya ke orang tua, saya mau menerima dengan target menikah beberapa tahun kemudian. Tapi ternyata rencana berubah dengan mendadak. Saya serasa menjalani pernikahan tersebut dengan "ngawang", setengah sadar." (Lt)

Hal yang sama juga dialami oleh Kh (32 th.) yang pada masa awal kehidupan rumah tangganya senantiasa terhimpit di antara dua perasaan yang bertolak-belakang, antara keinginan memberontak di satu sisi dan kesadaran akan ajaran agamanya yang melarang tindakan itu di sisi lain:

"Saya tahu akan dinikahkan ketika terop sudah berdiri. Saya waktu itu hanya bisa menangis karena tidak mungkin memberontak pada kemauan orang tua." (Kh)

Pengalaman lebih tragis dialami oleh $\mathrm{Kr}(29$ th. $)$ yang secara terpaksa mengorbankan cita-citanya untuk menempuh pendidikan pesantren pada jenjang yang lebih tinggi, karena harus menuruti kehendak neneknya yang menjodohkan dan menikahkannya dengan laki-laki yang belum dikenalnya:

"Saya berniat mondok ke Bangil. Saya sudah berkemas-kemas hendak berangkat keesokan harinya, ketika keluarga suami meminta saya ke nenek. Nenek adalah pemegang keputusan dalam hal pernikahan cucu-cucu perempuannya. Beliau sama 
sekali tidak meminta pertimbangan siapapun, termasuk saya atau orang tua saya. Beliau sudah menentukan hari pernikahan. Maka saya tidak jadi mondok. Saya sebenarnya sangat ingin mondok, tapi karena tidak ada yang berani menentang keputusan nenek, saya hanya bisa nangis menerima nasib.” (Kr)

Namun, uniknya, dari informan yang ada, beberapa di antaranya justru merasa menikmati perjodohan yang dilakukan orang tuanya atas dirinya. My (34 th.), misalnya, menyatakan:

"Pernikahan itu kemauan orang tua, tapi saya biasa aja, tidak merasa terpaksa ataupun senang sekali." (My)

Bahkan, Uh (28 th.) justru sering menceritakan rencana perkawinannya kepada teman-teman sekelasnya dengan perasaan suka. Sebuah indikasi kuat bahwa Uh sama sekali tidak mempersoalkan perjodohan oleh orang tuanya terhadapnya. Dia mengatakan:

"Meskipun dijodohkan, tapi kami sama-sama mau. Seringkali di kelas dia menjadi tema perbincangan saya dengan teman-teman." (Uh)

Sementara itu, dari perspektif legalitas perkawinan, para informan rata-rata melakukan pernikahan secara sirr, yakni pernikahan bawah tangan yang tidak didaftarkan secara resmi ke KUA, melainkan cukup dilaksanakan melalui upacara tradisional dengan melibatkan anggota keluarga dan beberapa tokoh sebagai saksi. Faktor usia perkawinan adalah faktor pendorong utama pihak keluarga dalam menikahkan anak perempuannya secara sirr serta tidak mencatatkannya secara resmi ke KUA. UU No. 1 Tahun telah mengatur batas minimal usia perkawinan (16 tahun untuk perempuan), sehingga KUA tidak dapat mengeluarkan surat nikah. Hal ini dinyatakan oleh $\mathrm{Kh}$ :

"Karena umur saya kurang waktu nikah, pernikahan kami tidak langsung dicatatkan di KUA. Setelah anak pertama saya berumur satu tahun, baru kami mencatatkan pernikahan kami di KUA." (Kh)

Kasus seperti Kh di atas mengandung konsekuensi yang cukup fatal karena usia anaknya lebih tua dari pada tanggal pernikahan yang tertera di surat nikah. Terlebih lagi tanggal anaknya sudah tertera di ijazahnya sehingga sulit untuk merekayasanya. 
Uniknya, beberapa informan melakukan pernikahan dini secara legal, dalam arti dicatakan di KUA, padahal usianya ketika itu belum memenuhi kriteria sebagaimana diatur oleh UU No. 1 Tahun 1974. Mf (37 th.), misalnya, menikah pada usia 14 tahun tapi ternyata dapat menikah secara legal formal di KUA. Dia bertutur:

"Pernikahan saya waktu itu langsung tercatat di KUA. Entah bagaimana caranya, mungkin usia saya agak dituakan dari kenyataannya." (Mf)

\section{POLA RELASI DALAM RUMAH TANGGA}

\subsection{Pola Relasi pada Awal Pernikahan}

Karena pernikahan dini para perempuan santri lebih banyak didasari oleh kehendak keluarga daripada kehendak sendiri, maka pada proses adaptasi dengan suami, terutama yang belum saling mengenal sebelumnya, terjadi upaya resistensi dari beberapa informan untuk melayani suaminya, terutama dalam hal hubungan badan. Mereka cenderung tidak mau "ngumpul" dengan suaminya. Dibutuhkan waktu yang beragam untuk meluluhkan hati para istri tersebut agar mau melayani suaminya, mulai dari hitungan hari hingga hitungan bulan. Hb bertutur:

\footnotetext{
"Setelah menikah, saya tidak melayani suami saya selama 3 bulan. Biasanya dia makan ditemani ayah saya. Pernah waktu saya disuruh melayaninya makan, saya bersembunyi di lemari pakaian, padahal dia makan di depan lemari itu bersama ayah saya. Saya diam di situ sampai semua selesai makan dan pergi. Tapi lama- kelamaan saya kasihan karena orangnya tidak pernah meminta atau memaksa. Walaupun saya membentak-bentaknya, dia diam saja. Akhirnya saya luluh. Tapi mungkin juga saya di “ewes-ewes" sehingga luluh." ( $\mathrm{Hb})$
}

Mf juga bertutur:

"Saya menikah pada tahun 1992, ketika saya masih kelas 2 Tsanawiyah, berumur 14 tahun. Suami saya waktu itu sudah berumur 32 tahun, duda tanpa anak. Waktu itu yang memutuskan pernikahan saya adalah orang tua dan orang tua angkat saya. Saya dipaksa. Saya sempat tidak "aromat" (Madura; merawat) suami selama 2 hari, tapi akhirnya mau, mungkin diewes-ewes sama orang tua. Kalau ndak, mungkin saya tetap ndak mau." (Mf) 
Tuturan yang sama juga disampaikan oleh $\mathrm{Kr}$ :

\begin{abstract}
"Kami saling tahu wajah ketika bersalaman setelah akad nikah. Pada malam pertama, dia tidur di ranjang, saya tidur di kolong ranjang. Saya tidak kumpul dengan suami sampai setengah bulan. Ibu saya tahu tapi tidak berani menegur karena paham saya menikah terpaksa. Walaupun saya tidak pernah kumpul dengan suami, tetapi saya tetap melayaninya dalam kebutuhan sehari-hari seperti mempersiapkan makan karena saya takut sama nenek. Setelah setengah bulan berlalu, saya jadi kasihan sama suami dicuekin terus. Apalagi dia tidak pernah menuntut apapun. Kata ibu, saya juga diewes-ewes oleh seorang kiai agar manut dan mau melayani suami." (Kr)
\end{abstract}

Satu hal menarik dari pola hubungan di awal pernikahan tersebut adalah adanya peran dukun atau kiai melalui doa-doa atau jampi-jampi agar istri-istri tersebut luluh hatinya. Terlepas dari apakah memang doa-doa itu yang membuat luluh ataukah sikap mengalah yang ditampakkan oleh suami tersebut, yang pasti seiring waktu para istri itu memang akhirnya mau melayani suaminya.

\title{
5.2. Pola Relasi Psikologis
}

Mengenai pihak yang dianggap memiliki keunggulan dari satu pihak di antara pasangan, para informan memiliki pendapat yang berbeda. Beberapa pasangan beranggapan suami memang memiliki keunggulan dalam beberapa segi, terutama dalam usia, penghasilan dan tingkat pendidikan. Anggapan ini sering membuat pihak istri minder terhadap suaminya. Hb menuturkan:

"Suami saya orangnya kasar dan meremehkan, sehingga saya kadang sangat minder. Di awal-awal masa perkawinan kami, saya sempat kaget, tapi akhirnya saya terbiasa. Dia memang lebih banyak kelebihan di banding saya, terutama dalam hal umur, penghasilan dan pendidikan." ( $\mathrm{Hb}$ )

Im juga menuturkan:

"Saya minder sama suami kalau dalam hal keilmuan. Terutama ketika mengerjakan tugas kuliah." (Im)

Dua orang informan di atas memang secara usia terpaut jauh dengan suaminya. Im 10 tahun sedangkan Hb 13 tahun. Begitu juga dalam hal pendidikan, suami kedua 
orang informan tersebut sudah menyandang gelar sarjana ketika menikah, sedangkan Im baru lulus SMA dan Hb hanya sempat mengecap pendidikan MI sebelum meneruskan ke pesantren an sich di Kediri. Pengalaman tersebut tidak terjadi pada pasangan yang relatif lebih dekat jarak usianya dan tingkat pendidikannya. Hal yang sama juga dijumpai pada pasangan yang berpikir positif bahwa setiap individu unik dan mimiliki kelebihan dan kekurangan. My menyatakan:

"Saya tidak pernah minder pada suami walaupun suami punya kelebihan kemampuan dibanding saya dalam hal keilmuan dan status sosial. Saya juga punya kelebihan yaitu lebih mudah bergaul disbanding suami." (My)

Lm juga mengatakan:

"Saya tidak merasa minder dengan suami, begitupun sebaliknya. Kami-kami samasama punya kelebihan dan kekurangan. Dia mungkin pintar kitab, tapi tidak mengerti sama sekali bahasa inggris. Sementara saya kitabnya pas-pasan tapi pernah belajar bahasa inggris dan matematika. Secara fisik, saya rasa kami juga punya kelebihan dan kekurangan masing-masing" (Lm)

Jarak usia Lm dengan suami hanya 5 tahun dan keduanya belajar di pesantren salaf yang sama. Dengan demikian memang tidak terdapat perbedaan yang mencolok dalam hal keunggulan yang dimiliki keduanya.

Dalam kasus yang berbeda, istri justru merasa lebih unggul dari suaminya terutama dalam hal fisik. Seperti yang diungkapkan oleh Ly:

"Saya tidak pernah merasa minder sama suami, justru saya merasa secara fisik lebih menarik dari pada suami." (Ly)

\subsection{Pola Komunikasi}

Pola komunikasi antar pasangan ini berbeda-beda. Terdapat informan yang pola komunikasinya tidak seimbang dalam arti satu pihak memposisikan lainnya di bawahnya. Hb bertutur: 


\begin{abstract}
"Suami saya orangnya kasar dan meremehkan, sehingga saya kadang sangat minder. Di awal-awal masa perkawinan kami, saya sempat kaget, tapi akhirnya saya terbiasa. Dia memang lebih banyak kelebihan di banding saya, terutama dalam hal umur, penghasilan dan pendidikan." (Hb)
\end{abstract}

Terdapat juga informan yang memiliki posisi yang sejajar dalam berkomuikasi. Hal ini tampak dari kedua belah pihak sangat mempertimbangkan pasangannya dalam memutuskan berbagai hal. Meskipun demikian, istri tetap memposisikan suami sebagai pihak yang lebih tinggi, sehingga kadang-kadang keputusan sepihak suami tidak dapat lagi di tawar. Hal seperti ini tidak selalu terjadi, tapi hanya dalam kasus tertentu yang tampaknya berkaitan dengan nilai yang diyakini suami. Lm bertutur:

"Kalau saya mau melakukan aktifitas tertentu, maka saya pasti izin ke suami, kalau tidak diperbolehkan saya tidak pernah maksa. Kalau tidak diridhoi suami, saya melakukannya tidak plong. .......................... Kalau kami tidak suka apa yang dilakukan pasangan kami diam, nanti kalau sudah tenang baru kami bicarakan. Misalnya, suatu saat pernah ada tamu laki-laki yang tidak dikenal mencari suami, karena suami sedang sholat, saya bukakan pintu dan saya persilahkan masuk. Setelah sholat suami bukan menemui tamu malah pergi dari pintu samping. Saya kebingungan ternyata suami saya tidak suka kalau saya membukakan pintu untuk tamu laki-laki yang tidak saya kenal. Sejak itu itu menjadi pelajaran dan tidak pernah mengulang lagi. Meski begitu saya tidak pernah mendapat perlakuaan kasar dari suami." (Lm)

Namun terdapat juga informan yang tampaknya benar-benar sejajar dalam berkomunikasi sehingga kedua belah pihak dapat mengekspresikan dirinya secara penuh. Hal ini tampak pada Ly dan pasangannya:

"Saya dan suami sering berbeda pendapat, jadi kami sering bertengkar tetapi tidak terlalu. Saya lebih sering dicuekin kalau marah-marah. Suami saya sangat bersih. Kalau saya nyuci hasilnya sering tidak cocok dengan suami. Nah kalau begitu, dia kadang marah. Suami juga tidak suka ngerasani orang, tapi saya suka ngegosip. Kalau saya ngegosip biasanya dia menegur, tapi saya lebih sering tetap ngegosip. Kalau sudah gitu kami agak cekcok. Tapi kalau sudah ya sudah..... suami tidak pernah memperlakukan saya dengan kasar apalagi memukul." (Ly)

\title{
5.4. Pola Pengambilan Keputusan
}


Hampir semua informan menempatkan suami sebagai pemegang keputusan dalam keluarga, terutama dalam hal-hal yang dianggap besar dan urgen. Posisi tersebut bisa diberikan istri secara sadar dan sukarela ataupun memang tanpa perlu menanyakan pendapat istri. Dalam kasus My, misalnya, suaminya menjadi pemegang keputusan dalam keluarga karena memang dia sadar bahwa keputusan suami selama ini lebih bisa dipertanggungjawabkan daripada keputusannya sendiri. My berkisah:

\begin{abstract}
"Kami saling tidak punya beban dalam menyampaikan keinginan. Begitupun ketika ada masalah, kami tidak punya beban untuk mulai membicarakan lebih dulu. Tapi keputusan akhir lebih banyak pada suami. Saya hampir tidak pernah menjadi pengambil keputusan karena saya takut keliru. Pernah saya memutuskan sesuatu dan ternyata keputusan saya tidak tepat, suami saya "maidhu" (jawa). Sejak saat itu saya selalu menyerahkan pengambilan keputusan pada suami." (My)
\end{abstract}

Berbeda dengan kasus Im yang memang tidak diberi ruang oleh suaminya untuk turut serta dalampengambilan keputusan. Saran-saran atau pendapatnya lebih sering tidak menjadi pertimbangan suami dalam membuat keputusan, bahkan yang paling remeh sekalipun. Im bertutur:

"Suami saya orangnya sangat sabar pada istri, saya hampir tidak pernah dimarahin. Tapi dalam banyak hal keputusan sepenuhnya ada di tangannya. Pilih barang seperti kulkas, bahkan baju saya kadang dipilihin sehingga tidak sesuai dengan selera saya dan tidak pernah saya pakek. Terlebih lagi ketika membangun rumah, ide-ide saya tidak pernah dipakai. Bentuk rumah hingga warna cat sepenuhnya suami yang memutuskan." (Im)

Meskipun demikian, terdapat informan yang saling mempertimbangkan pendapat pasangan dalam pengambilan keputusan. Lm bertutur:

"Kalau saya mau melakukan aktifitas tertentu, maka saya pasti izin ke suami, kalau tidak diperbolehkan saya tidak pernah maksa. Kalau tidak diridhoi suami, dan saya melakukan tidak plong. ...... Suami juga begitu, kalau saya agak berat, dia bersikap hal yang sama. Mungkin karena kami tidak terlalu jauh usianya, karenanya saling bisa mengimbangi." (Lm) 
Dalam hal keuangan, posisi suami pada hampir semua informan adalah sebagai pencari nafkah. Kalaupun istri juga punya penghasilan, tapi jumlahnya lebih sedikit sehingga menjadi nafkah sekunder saja. Hb mengatakan:

"Dalam hal keuangan, pengelolaan ada di tangan suami. Saya hanya diberi uang belanja kebutuhan sehari-hari. Bagi saya ndak masalah karena kalau saya yang pegang bisa-bisa hari ini makan besok ndak makan apa-apa. Saya orangnya boros banget. Tapi penghasilan saya tidak diganggu gugat. Saya bisa sepenuhnya menggunakannya untuk kepentingan saya sendiri. Belanja adalah kewajiban suami." $(\mathrm{Hb})$

Bahkan di antara para informan ada yang sama sekali tidak bekerja sehingga tidak punya penghasilan sendiri. Ly menyatakan:

"Penghasilan keluarga 100\% dari suami, saya tidak mempunyai penghasilan. Dalam hal belanja, suami tiap hari memberi saya uang untuk belanja dalam jumlah yang tetap. Tapi kalau kurang ya saya minta lebih. Atau misalnya ada barang lain yang harus saya beli yang saya minta dan suami selalu ngasih selama masih punya uang. Suami saya tidak pernah perhitungan sama keuangan, tetapi saya hati-hati sendiri, malu sama suami." (Ly)

Namun, uniknya, ada seorang informan yang menjadi tulang punggung keluarga. Setelah suaminya semakin berkurang kemampuan fisiknya, ia meneruskan bisnis suaminya. Mf, misalnya, menyatakan:

"Akhir-akhir ini suami saya sakit jantung dan tergantung pada obat hingga pendengarannya sangat berkurang. Keuangan keluarga sepenuhnya saya yang mengurusi. Dia tinggal minta ke saya." (Mf)

Selanjutnya, dalam hubungan seksual, tiap informan memiliki dinamika sendiri. Bagi sebagian informan, hubungan seksual menjadi beban karena beberapa alasan. Pertama, karena secara fisik sering tidak siap karena terlalu lelah dengan aktifitas sehari-hari, sebagaimana dialami oleh Kh:

"Dalam hubungan seksual, kami jarang berhubungan. Saya lebih sering menolak berhubungan karena saya capek dan malas. Biasanya kalau suami pengen dan saya tolak, suami 'nggeremeng', tapi saya biarin aja." (Kh) 


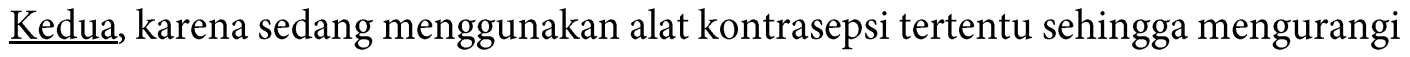
gairah secara signifikan, seperti dituturkan oleh Ly:

"Tentang hubungan seksual kadang saya juga terpaksa melayani suami terutama setelah saya ikut KB suntik. Sebenarnya ndak pengen KB tapi kami juga tidak mau kalau jarak anak terlalu dekat. Jadi ya saya tetap ikut KB meskipun sangat berpengaruh pada gairah saya. Tapi kalau sudah tidak KB saya lebih sering tidak terpaksa melayani suami." (Ly)

Ketiga, karena momen yang kurang pas, seperti dkisahkan oleh My:

"Dalam hubungan seksual, inisiatif bisa dari dua belah pihak. Tapi kadang saya juga malu. Kadang juga saya merasa terpaksa. Suami saya meleknya malam, tidurnya siang. Seringkali saya sedang tidur malam, dibangunin suami dan diajak berhubungan badan. Walau terpaksa ya tetap saya layani, habisnya tetap dipaksa." (My)

Bagi sebagian informan lain, hal itu tidak menjadi kendala karena bisa didialogkan dengan suami. Kalaupun terpaksa melakukannya, informan tetap berharap menjadi ibadah. Lt menuturkan:

"Dalam hubungan badan, ketika saya tidak siap kadang menolaknya, tapi kadang juga terpaksa melayani agar suami tidak merengut. Lagian saya berharap pahalanya banyak. Apalagi ada hadits tentang laknat malaikat itu. Tapi kalau saya betul-betul tidak siap, ajaran itu ya saya abaikan." (Lt)

Lm juga bertutur:

"Dalam hubungan badan kami selalu mendialogkan. Kalau salah satu sedang tidak mood yang lain tidak memaksa, tetapi jarang tidak mood kok. Mungkin karena tenaga kami tidak pernah terforsir. Anak-anak dan semua pekerjaan rumah ada yang membantu." (Lm)

Namun, satu temuan menarik adalah adanya seorang informan yang tidak pernah menjadikannya sebagai beban, seperti yang dirasakan oleh $\mathrm{Hb}$ :

"Saya tidak pernah merasa terpaksa dalam berhubungan badan. Bahkan seringkali saya yang berinisiatif. Jadi dalam hal itu kami baik-baik saja." (Hb) 


\title{
5.5. Kekerasan dalam Rumah Tangga
}

Beberapa informan pernah mengalami kekerasan dari suami berupa kekerasan psikologis seperti meremehkan istri atau marah-marah terhadap istri. Seorang informan pernah dipukul suaminya karena cemburu. Tapi pemukulan tersebut, menurut istrinya lebih karena penyakit phobia yang diidapnya. My bertutur:

"Suami saya punya penyakit takut dan khawatir berlebihan. Dulu pernah dia selalu takut mati. Beberapa waktu yang lalu dia punya kecurigaan saya ada main dengan seorang santri di pondok. Saya pernah dipukul karena cemburu. Itu masalah yang terbesar yang pernah dihadapi rumah tangga kami. Orang tua sampai terlibat." (My)

Seorang informan pernah mengalami tekanan dari suami untuk menyetujuinya menikah lagi dengan perempuan lain, hingga beberapa kali. Tapi kemauannya tersebut tidak terjadi karena adanya penolakan dari perempuan yang akan dinikahi. $\mathrm{Hb}$ bertutur:

\begin{abstract}
"Suami saya orangnya kasar dan meremehkan, sehingga saya kadang sangat minder....... Masalah terbesar yang pernah saya hadapi dalam komunikasi dengan suami adalah ketika dia ingin menikah lagi dengan seorang syarifah. Waktu itu saya sedang hamil anak ketiga. Saya benar-benar tertekan waktu itu, tapi suami selalu mengulang tentang istri solehah. Saya pun terpaksa manut dan "memintakan" sendiri pada perempuan itu, walaupun sebenarnya saya stress berat. Saya merasa diabaikan ketika dalam masa hamil. Tapi untungnya syarifah itu tidak mau. Setelah itu, saya tidak bakal lagi mau mengulang kisah yang sama. Sebelumya suami saya sudah dua kali meminta hal yang sama dengan perempuan lain. Tapi untungnya mereka juga menolak." $(\mathrm{Hb})$
\end{abstract}

Ada informan yang menganggap bahwa kekerasan yang dilakukan suami lebih karena karakter suami yang memang keras hati dan mudah marah. Tetapi kemarahan tersebut hanya ditumpahkan pada barang-barang tidak sampai memukul istri atau anak-anaknya. Seperti yang dialami oleh $\mathrm{Kr}$.

"Dalam relasi suami istri, saya lebih banyak mengalah dan sabar. Ternyata suami saya orangnya sangat keras. Kalau marah dia sering mengamuk memukul meja atau melempar barang. Kadang dia marah ke saya di hadapan anak-anak. Kalau begitu saya segera menyingkir dari pada berkepanjangan. Anak-anak paham posisi saya." $(\mathrm{Kr})$ 
Mf juga mengalami hal yang sama:

"Suami saya orangnya keras, suka marah. Sejak awal pernikahan dia sudah menegaskan itu. Dia bilang 'kalau kau bisa mengambil hatiku, kitaa kan hidup bersama sampai tua'. Saya tidak pernah melawan suami, takut. Lagian kalau salah wajar dimarahin. Saya mengalah aja, apalagi anak sudah besar-besar." (Mf)

Dalam menanggapi kekerasan yang dialaminya, para istri bersikap menerima dan pasrah. Dalam beberapa kasus, mereka berusaha memaklumi sikap suami tersebut sebagai imbas dari kepayahan fisik atau karena suami menderita penyakit tertentu, sehingga kekerasan yang dilakukannya bukan karena sifat aslinya, tapi karena faktor di luar dirinya. Seperti dituturkan oleh My:

"Tapi saya tahu itu bukan karakter suami saya yang sebenarnya karena pada dasarnya dia sangat penyabar. Hanya saja dia punya penyakit phobi itu. Kadang dia takut dengan sesuatu yang sebenarnya tidak ada atau belum dihadapi.” (My)

dan dituturkan oleh $\mathrm{Kr}$ :

"Saya juga maklum, kerja suami saya tidak kenal waktu. Siang dia ngajar, malam merakit atau memperbaiki computer hingga malam, kadang hingga dini hari." (Kr)

Anak juga menjadi pertimbangan istri untuk bersikap mengalah dalam menghadapi sikap keras suami. Di samping memang adanya rasa takut untuk melawan.

"Saya tidak pernah melawan suami, takut. Lagian kalau salah wajar dimarahin. Saya mengalah aja, apalagi anak sudah besar-besar." (Mf)

Jarak usia Mf yang sangat jauh dari usia suaminya (19 tahun) bisa jadi menjadi faktor yang sangat menentukan pada sikap mengalah yang diambil oleh Mf.

\subsection{Sikap dalam Berumah Tangga}

Terdapat beberapa faktor yang menjadi dasar para informan dalam membangun relasi dengan suami. Di antaranya adalah karena faktor role-model dari ligkungannya, internalisasi ajaran agama, dan ketergantungan terhadap suami. 
Cara orang tua atau lingkungan sekitar bersikap dalam rumah tangga sangat mempengaruhi beberapa informan dan membentuk sifta dan sikat mereka terhadap keluarganya terutama terhadap suaminya. Seperti Lm yang tidak pernah melakukan aktifitas diluar aktifitas rumah tangga tanpa seizing suaminya. Sikap dia tersebut, di samping memang dipengaruhi juga internalisasi ajaran di pesantren.

\begin{abstract}
"Selama nikah sirri kami tidak pernah kumpul, saya tidak mau karena saya tahu bahwa selama suami belum memberi nafkah maka istri belum wajib taat sepenuhnya. Karena taat itu kompensasi mahar dan nafkah. ...Kalau saya mau melakukan aktifitas tertentu, maka saya pasti izin ke suami, kalau tidak diperbolehkan saya tidak pernah maksa. Kalau tidak diridhoi suami, dan saya melakukan tidak plong. Saya bersikap begitu karena mencontoh, ibu, nenek dan orang-orang di lingkungan saya." (Lm)
\end{abstract}

Pengaruh ajaran fiqh yang diinternalisasikan secara intensif di lingkungan pesantren sangat menentukan sikap beberapa informan dalam bersikap terhadap suami. Seperti pengakuan Im berikut ini:

"Walaupun sebelum menikah saya tidak mau dengan calon suami, setelah menikah saya langsung menjadi istri yang baik karena saya selalu teringat pesan Kiai dan Ibu Nyai saya di pondok 'santriku harus taat pada suami'. Di pondok tempat saya belajar, tatakrama menjadi istri shalihah memang ditekankan. Santri baru langsung ngaji kitab 'Uqūd al-Lujain jenggotan pada Bu NYai Sepuh.” (Im)

dan tuturan My di bawah ini:

"Saya menjalani kehidupan rumah tangga ini ya dengan cara yang muncul dengan sendirinya, bukan dari pelajaran atau pun role model. Kalau sekarang saya belajar dari buku-buku Islam dan TV. Kadang saya belajar dari film anak-anak, kata-kata bijak yang ada di sana." (My)

Namun, faktor ketergantungan terhadap suami, terutama dalam hal ekonomi, juga menjadi pertimbangan dominan bagi sebagian informan dalam menentukan sikapnya untuuk taat terhadap suaminya. Seperti Hb yang mengakui bahwa meskipun dia mengenyam pendidikan pesantren selama beberapa tahun, ajaran fiqh yang dipelajarinya sama sekalil menjadi pertimbangan untuk taat pada suami. Sikap taat itu lebih karena ketergantungannya kepada suami secara finansial. Dia mengatakan: 
"Ketaatan saya pada suami bukan karena pelajaran yang saya peroleh di pesantren, sama sekali bukan. Saya taat karena saya sepenuhnya bergantung pada suami secara ekonomi. Seandainya saya memiliki penghasilan yang jauh lebih besar dari suami, saya mungkin akan menjadi seorang istri yang kurang ajar.” (Hb)

Temuan yang menarik adalah bahwa di antara para informan hanya segelintir orang saja yang merasa menyesal telah menikah muda. Bentuk penyesalan tersebut ditumpahkan pada harapan bahwa anak-anaknya akan meraih cita-citanya hingga berhasil. Seperti dikatakan oleh Kh:

"Saya tidak ingin anak-anak saya seperti saya. Biar mereka memutuskan jalan hidup mereka sendiri." (Kh)

Mayoritas informan tidak merasakan penyesalan telah menikah muda dengan berbagai alasan. Seperti dituturkan oleh My:

"Saya bahagia dalam menjalani rumah tangga ini. Walaupun kadang tidak sesuai dengan keinginan, tapi tidak apa, bisa saya tahan. Perempuan memang harus berkorban." (My)

Di antara mereka ada yang menganggap bahwa pernikahan justru memberikan ruang yang banyak baginya untuk belajar tentang berbagai hal dibanding ketika ia belum menikah. Lt bertutur:

"Secara umum saya bahagia dan tidak pernah menyesal menikah dini karena ternyata menikah bukan berarti menghentikan segalanya. Terlebih lagi, saya banyak belajar setelah menikah. Belajar dari suami, dan dari lingkungan. Setelah menikah khan saya bergaulnya dengan orang-orang dewasa, tidak lagi dengan remaja yang cuma ngobrolin yang senang-senang." (Lt)

Faktor ajaran fiqh juga menjadi alasan mereka mensyukuri pernikahan dini yang mereka alami. Seperti yang diungkapkan oleh Lm:

"Saya tidak pernah menyesal menikah muda dan menikah sirri. Justru saya bersukur karena saya terhindar dari dosa; pacaran sebelum menikah.” (Lm) 
Faktor comfort life juga menjadi pertimbangan bagi sebagian informan. Pernikahan muda tidak layak disesali karena suami sudah mencukupi baik secara material maupun non-material. Hb menegaskan:

"Aku tidak pernah menyesal menikah muda karena suamiku sudah mencukupiku baik secara materi maupun non-materi." ( $\mathrm{Hb})$

Uraian tentang posisi perempuan santri dalam pernikahan dini yang telah dipaparkan di atas tersaji dalam tabel berikut:

Tabel 1:

Posisi Perempuan Santri dalam Relasi Pernikahan Dini

\begin{tabular}{|c|c|c|}
\hline No. & Aspek Equality & Temuan \\
\hline 1 & $\begin{array}{l}\text { Sikap tidak } \\
\text { mengancam }\end{array}$ & $\begin{array}{l}\text { Kasus } \mathrm{Kr} \text { yang berupa ancaman sikap suami yang kadang } \\
\text { meluapkan emosi secara meledak-ledak dan Mf yang suaminya } \\
\text { secara lisan "mengancam" jika Mf tidak bisa memahami dirinya } \\
\text { dan mengambil hatinya maka tidak akan bisa lama } \\
\text { mendampinginya. } \\
\text { Sengaja atau tidak sikap tersebut adalah sikap yang mengancam } \\
\text { terhadap para informan. Namun informan lebih bersikap } \\
\text { menerima dan menyesuaikan diri dengan kondisi tersebut. }\end{array}$ \\
\hline 2 & $\begin{array}{l}\text { Sikap menghar- } \\
\text { gai }\end{array}$ & $\begin{array}{l}\text { Dalam hal ini, kasus } \mathrm{Hb} \text { menjadi kasus yang cukup menonjol } \\
\text { dalam hal pemahaman pasangan terhada kondisinya. } \\
\text { Kekurangan informan seringkai menjadi sebab bagi pasangan } \\
\text { untuk meremehkannya. } \\
\text { Sementara itu Im tidak dipertimbangkan pendapatnya oleh } \\
\text { pasangan. Bahkan dalam urusan pribadi Im pun, pasangannya } \\
\text { seringkali memutuskan pilihan-pilihannya. }\end{array}$ \\
\hline 3 & $\begin{array}{l}\text { Kepercayaan } \\
\text { dan dukungan }\end{array}$ & $\begin{array}{l}\text { Kasus tidak percaya pada pasangan ditemukan pada My yang } \\
\text { dicurigai bermain dengan orang lain. Kecurigaan ini disinyalir } \\
\text { lebih karena adanya kelainan psikis pada suami bukan karena } \\
\text { adanya perubahan sikap atau gelagat "perselingkuhan" istri. }\end{array}$ \\
\hline 4 & $\begin{array}{l}\text { Jujur dan ber- } \\
\text { tanggung jawab }\end{array}$ & $\begin{array}{l}\text { Tidak terdapat temuan yang menunjukkan ketidakjujuran atau- } \\
\text { pun sikap tidak bertanggung jawab pada setiap pasangan in- } \\
\text { forman }\end{array}$ \\
\hline
\end{tabular}




\begin{tabular}{|c|c|c|}
\hline No. & Aspek Equality & Temuan \\
\hline 5 & $\begin{array}{l}\text { Tanggung jawab } \\
\text { sebagai orang } \\
\text { tua }\end{array}$ & $\begin{array}{l}\text { Setiap pasangan informan menjadikan anak sebagai salah satu } \\
\text { faktor orientasi keluarga sehingga dalam mengambil keputusan } \\
\text { atau bersikap, anak menjadi salah satu pertimbangan yang sangat } \\
\text { penting. Namun demikian, terdapat pasangan yang kerap men- } \\
\text { ampakkan kekerasan terhadap pasangan di hadapan anak-anak- } \\
\text { nya yaitu Kr dengan karakter suaminya yang keras, dan My ka- } \\
\text { rena penyakit yang diidap suaminya. }\end{array}$ \\
\hline 6 & $\begin{array}{l}\text { Pembagian hak } \\
\text { dan wewenang }\end{array}$ & $\begin{array}{l}\text { Tidak ditemukan persoalan. Meskipun memang pembagian } \\
\text { peran berdasarkan gender masih sangat lekat, akan tetapi pada } \\
\text { umumnya para suami mau mengerti kesibukan istri di luar rumah } \\
\text { tangga, misalnya kesibukan sebagai guru, kepala sekolah, } \\
\text { mahasiswi maupun bisnis. }\end{array}$ \\
\hline 7 & $\begin{array}{l}\text { Kemitraan } \\
\text { ekonomi }\end{array}$ & $\begin{array}{l}\text { Dalam hal ini tidak ditemui persoalan. Meskipun mayoritas } \\
\text { informan masih menjadikan suami sebagai pencari nafkah utama, } \\
\text { namun istri juga telah memeroleh akses terhadap pengembangan } \\
\text { ekonominya sendiri. Di samping itu, dalam pengelolaan } \\
\text { keuangan, edua belah pihak dilibatkan dengan keunikannya } \\
\text { masing-masing dalam tiap pasangan. }\end{array}$ \\
\hline 8 & $\begin{array}{l}\text { Negosiasi dan } \\
\text { bersikap adil }\end{array}$ & $\begin{array}{l}\text { Negosiasi tampaknya tetap menjadi pilihan yang terbaik dalam } \\
\text { setiap pasangan informan. Akan tetapi, dalam proses negosiasi } \\
\text { tersebut, persepsi tiap kepala dalam relasi terhadap pasangannya } \\
\text { sangat menentukan pola negosiasi dan juga out-putnya. Pada in- } \\
\text { forman yang menganggap pasangannya sebagai mitra sejajar, ne- } \\
\text { gosiasi tersebut terlihat imbang, seperti kasus My dan Kh. Se- } \\
\text { dangkan yang menganggap pasangan sebagai pihak yang lebih } \\
\text { tinggi, maka negosiasi lebih tidak seimbang, seperti pada kasus } \\
\text { Im, Lm, dan Hb. Namun demikian, tidak setiap bentuk negosiasi } \\
\text { dalam setiap pasangan bersifat sama. Dalam satu pasangan, ka- } \\
\text { dang tidak seimbang dalam negosiasi tertentu tapi seimbang da- } \\
\text { lam yang lain. Hal ini tampaknya juga dipengaruhi oleh persepsi } \\
\text { yang berbeda tentang urgensitas suatu permasalahan dalam } \\
\text { keluarga. }\end{array}$ \\
\hline
\end{tabular}




\section{KOMITMEN TERHADAP RUMAH TANGGA}

Secara umum informan tidak menyesal melakukan pernikahan dini. Mereka sama sekali tidak memiliki keinginan untuk bercerai. Alasannya cukup beragam, sebagaimana tersaji pada tabel berikut:

Tabel 2:

Respon Perempuan Santri terhadap Relasi Penikahan Dini

\begin{tabular}{|l|l|l|}
\hline \multicolumn{1}{|c|}{ Respon } & \multicolumn{1}{|c|}{ Alasan } & Keterangan \\
\hline $\begin{array}{l}\text { Tidak } \\
\text { menyesal }\end{array}$ & $-\begin{array}{l}\text { Terhindar fitnah } \\
\text { Comfort life (ekonomi) } \\
\text { Lebih banyak ruang untuk belajar dan menjadi } \\
\text { lebih dewasa }\end{array}$ & $\begin{array}{l}\text { Mayoritas } \\
\text { informan }\end{array}$ \\
\hline - Menyesal & $\begin{array}{l}\text { Banyak mengalami kejadian yang tidak me- } \\
\text { nyenangkan, seperti baby blue (merasa tidak sa- } \\
\text { yang dengan anaknya yang baru lahir) }\end{array}$ & $\begin{array}{l}\text { Hanya } \\
\text { beberapa } \\
\text { informan }\end{array}$ \\
\hline
\end{tabular}

Sikap informan ini adalah akumulasi dari pengalaman kenyataan obyektif dan internalisasi nilai-nilai yang dalam kehidupan yang dihayati. Semua informan dalam pengamatan peneliti semua mampu berdamai dengan kondisi paska pernikahan, meski yang awalnya dipaksa. Dalam rentang waktu sekian tahun dari pernikahan, sebagaimana tabel diatas, hampir semua tidak merasakan menyesal atas pernikahan dini yang dilakukan. Dalam amatan peneliti, sikap menerima atas kejadian masa lalu tersebut disebabkan tidak adanya kondisi negatif yang ekstrem yang menyebabkan mereka merasa tertekan. Meski dalam penilaian peneliti acapkali menerima berbagai bentuk ketidakkesetaraan mereka terkadang menganggap hal tersebut bukan menjadi masalah, sebagaimana dijelaskan tabel dibawah.

Ragam kondisi yang tidak menyenangkan bagi informan bukan sesuatu yang perlu dipermasalahkan, sebab yang terpenting adalah menjaga keutuhan rumah tangga. Bahkan salah satu informan dengan berat hati memberi izin kepada suaminya untuk poligami dengan alasan demi keutuhan dan harmoni rumah tangga. Posisi anakanak mereka juga menjadi faktor utama dalam perempuan mengambil respon yang demikian. Singkatnya keutuhan rumah tangga dan anak menjadi yang diutamakan, 
adapun perlakuan kekerasan yang dilakukan suami bukan menjadi hal yang patut untuk diperbincangkan dan didialogkan dengan pasangan.

Pengaruh ajaran agama (fiqh) tentang hak suami dan istri yang diajarkan dipesantren ternyata juga mempengaruhi cara mereka menerima keadaan. Sikap tunduk dan pasrah terhadap sikap suami dipercaya sebagai bentuk nyata dari pengamalan ajaran agama tentang istri yang solehah.

Tabel 3:

Kekerasan yang Dialami Perempuan Santri dalam Relasi Rumah Tangga Pernikahan Dini

\begin{tabular}{|l|l|l|}
\hline Jenis Kekerasan & \multicolumn{1}{|c|}{ Bentuk kekerasan } & \multicolumn{1}{|c|}{ Respon } \\
\hline Kekerasan fisik & $\begin{array}{l}\text { Dipukul karena cem- } \\
\text { buru }\end{array}$ & Menerima dan memaklumi \\
\hline Kekerasan Psikis & $\begin{array}{l}\text { Diremehkan } \\
\text { Mau dipoligami }\end{array}$ & $\begin{array}{l}\text { Pasrah dan menerima } \\
-\end{array}$ \\
\hline $\begin{array}{l}\text { Kekerasan Sek- } \\
\text { sual }\end{array}$ & $\begin{array}{l}\text { Terpaksa berhub- } \\
\text { ungan badan dengan norma agama }\end{array}$ \\
\hline $\begin{array}{l}\text { Kekerasan } \\
\text { ekonomi }\end{array}$ & - & $\begin{array}{l}\text { Menerima } \\
\text { Tunduk dengan norma agama dengan } \\
\text { harapan pahala } \\
\text { Cuek dan tidak menikmati yang pent- } \\
\text { ing keluarga aman dan menjadikannya } \\
\text { sebagai rutinitas saja }\end{array}$ \\
\hline
\end{tabular}

\section{KESIMPULAN}

Berdasarkan hasil penelitian di atas serta dikaitkan dengan fokus penelitian ini, bisa diperoleh kesimpulan sebagai berikut:

a. Tradisi pernikahan dini komunitas santri Kabupaten Malang berakar kepada pemahaman keagamaan, budaya, dan ekonomi. Namun, dua latar pertama jauh lebih dominan daripada latar ketiga.

b. Pola relasi rumah tangga hasil pernikahan dini komunitas santri Kabupaten Malang memang diwarnai oleh sejumlah bentuk kekerasan, 
namun rata-rata bisa diatasi melalui serangkaian proses adaptasi dan komunikasi antara suami-istri.

c. Komunitas santri pelaku pernikahan dini Kabupaten Malang rata-rata memiliki komitmen kuat untuk mempertahankan pernikahannya. Komitmen tersebut dilandasi oleh latar agama dan budaya yang telah mereka yakini dan anut dengan kuat secara turun-temurun.

Dengan demikian, penelitian yang dilakukan selama enam bulan pada tahun 20112012 ini menghasilkan sebuah temuan bahwa pernikahan dini, betapapun memuat ragam bentuk kekerasan, baik dalam bentuk fisik, psikologis maupun seksual, tidak dengan serta-merta dinyatakan menjadi faktor perceraian. Mengapa, pernikahan dini, utamanya yang dilakukan oleh perempuan santri, memiliki keunikan dan kompleksitas tersendiri.

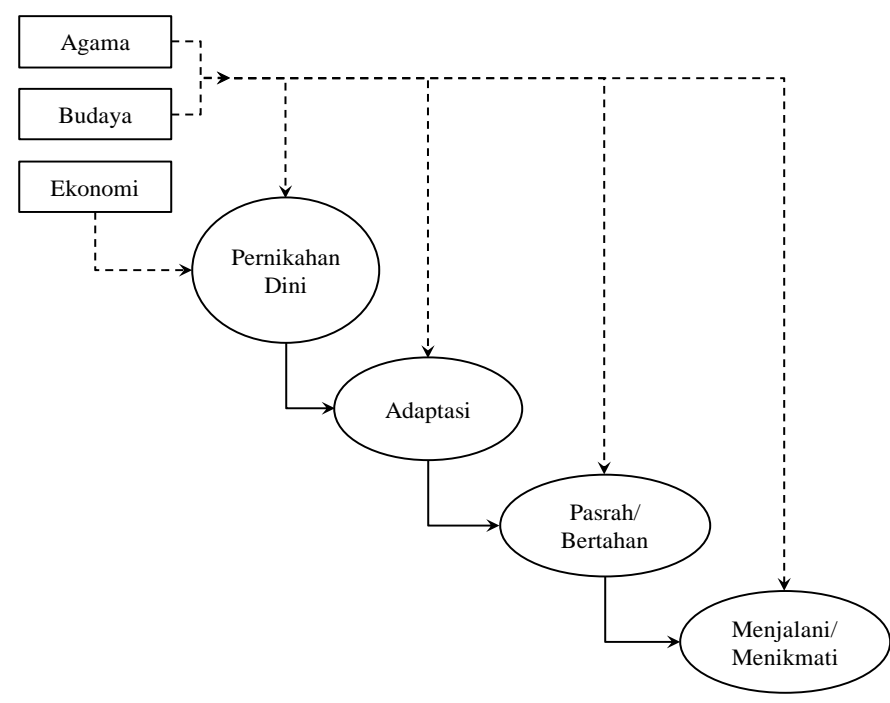

Gambar 3. Peran Agama dan Budaya

Tegasnya, temuan penelitian ini sekaligus mementahkan tesis sejumlah kalangan selama ini bahwa pernikahan dini dapat menjadi pemicu tingginya angka perceraian dan bahkan perdagangan (trafficking) perempuan dan anak. [] 


\section{REFERENCES}

Adams, Catherine, dan Max van Manen. 2008. "Phenomenology". Dalam Lisa M. Given (ed.), The Sage Encyclopedia of Qualitative Research Methods. Cetakan I. California: SAGE Publications, Inc.

Afifah, Zuni. 2010. "Pandangan Santri Nurul Ummah terhadap Kekerasan dalam Rumah Tangga menurut UU No. 23 Tahun 2004”. Skripsi. Yogyakarta: UIN Sunan Kalijaga.

Babcock, Julia C., dkk. 1993. "Power and Violence: The Relation Between Communication Patterns, Power Discrepancies, and Domestic Violence". Journal of Consulting and Clinical Psychology, Vol. 61, No. 1, Tahun 1993

Bappenas. 2007. Laporan Perkembangan Pencapaian Millennium Development Goals Indonesia 2007. Nopember 2007.

al-Bantanī, Nawawī al-, al-Jāwī. T.t. 'Uqūd al-Lujayn fì Bayān Huqūq al-Zawjayn. Semarang: Usaha Keluarga.

Creswell, John W. 1998. Qualitative Inquiry and Research Design: Choosing among Five Traditins. Cetakan I. California: SAGE Publications, Inc.

Dhofier, Zamakhsyari. 1982. Tradisi Pesantren Studi tentang Pandangan Hidup Kyai. Cetakan I. Jakarta, LP3ES.

Evelyn Suleeman. 1999. "Hubungan-hubungan dalam Keluarga". Dalam T.O. Ihromi (ed.), Bunga Rampai Sosiologi Keluarga. Cetakan I. Jakarta: Yayasan Obor Indonesia.

Jauharin, Adib. 2000. "Beberapa Faktor yang Berhubungan dengan Pendapat Santri Pondok Pesantren tentang Perkawinan Usia Dini bagi Wanita: Studi di Pondok Pesantren Fathul Huda Desa Sidorejo Kecamatan Sayung Kabupaten Demak". Skripsi. Semarang, Universitas Diponegoro.

Adhim, Mohammad Fauzil. 2002. Indahnya Pernikahan Dini. Cetakan I. Jakarta: Gema Insani Press. 
Firth, Raymond. 2006. "An Anthropological Approach to the Study of Religion". Dalam Russel T. McCutcheon (ed.), The Insider/Outsider Problem in the Study of Religion: A Reader. Cetakan I. London dan New York: Casell.

Forum Kajian Kitab Kuning (FK3). 2001. Wajah Baru Relasi Suami Istri: Telaah Kitab 'Uqüd al-Lujjayn. Cetakan I. Yogyakarta: LKiS.

Geertz, Clifford. 1960. The Religion of Java. Chicago: University of Chicago Press.

Given, Lisa M., dan Kristie Saumure. 2008. “Trustworthiness”. Dalam Lisa M. Given (ed.), The Sage Encyclopedia of Qualitative Research Methods. Cetakan I. California: SAGE Publications, Inc.

Hamidi, Jazim, dkk. 2007. "Persepsi dan Sikap Masyarakat Santri Jawa Timur terhadap Bank Sari'ah". Jurnal Keuangan dan Perbankan, Universitas Merdeka Malang. Tahun XI, Nomor 3, September 2007.

Idraswari dkk. 1998. "Fenomena Kawin Muda dan Aborsi: Gambaran Kasus". Laporan Penelitian. Jakarta: Rahima, Pusat Pendidikan dan Informasi Islam dan Hak-hak Perempuan.

Lamanna, Mary Ann, dan Agnes Riedmann. 2009. Marriages and Families: Making Choices in a Diverse Society. Cetakan X. California: Wadsworth Publishing.

Liestyasari, Siany Indria. 2006. "Konstruksi Sosial Kultural Poligini dalam Pesantren”. Jurnal Sosiologi DILEMA, Universitas Sebelas Maret Surakarta. Vol. 18 No. 2 Th. 2006.

Madjid, Nurcholish. 1997. Bilik-bilik Pesantren: Sebuah Potret Perjalanan. Cetakan I. Jakarta: Paramadina.

Mahmood, Tahir. 1987. Personal Law in Islamic Countires: History, Text and Comparative Analysis. New Delhi: Academy of Law and Religion.

Miles, Matthew B., dan Michael Huberman. 1994. Qualitative Data Analysis: An Expanded Sourcebook. Cetakan II. California: SAGE Publications Inc.

Morgan, David L. 2008. "Snowball Sampling”. Dalam Lisa M. Given (ed.), The Sage Encyclopedia of Qualitative Research Methods. Cetakan I. California: SAGE Publications, Inc. 
Mulkhan, Abdul Munir 1994. Runtuhnya Mitos Politik Santri: Strategi Kebudayaan Islam. Cetakan I. Yogyakarta: Sipress.

al-Qudhāt, Mushthafā. 2010. “Al-Tabkīr fĩ al-Zawāj wa al-Ātsār al-Mutarattibah 'alayh”. Majallah Jāmi'ah Dimisyq li al-'Ulūm al-Iqtishādiyyah wa alQānūniyyah. Edisi 26, Nomor I, Tahun 2010.

Rahardjo, Mudjia. 2010. “Analisis Data dalam Penelitian Kualitatif (11 Juni 2010)”. Http://www.mudjiarahardjo.com (akses tanggal 13 Mei 2011).

Raco, J.R. 2010. Metode Penelitian Kualitatif: Jenis, Karakteristik dan Keunggulannya. Cetakan I. Jakarta: Grasindo, 2010

Thohir, Mudjahirin. 2009. "Makna Khoul bagi Komunitas Santri (6 Maret 2009)". Http://staff.undip.ac.id (akses tanggal 13 Mei 2011).

Shaw, Rosalind. 2006. "Feminist Anthropology and the Gendering of Religious Studies". Dalam Russel T. McCutcheon (ed.), The Insider/Outsider Problem in the Study of Religion: A Reader. Cetakan I. London dan New York: Casell.

Surbakti, E.B. 2008. Sudah Siapkah Menikah?: Panduan bagi Siapa Saja yang Sedang dalam Proses Menentukan Hal Penting dalam Hidup. Cetakan I. Jakarta: PT Elex Media Komputindo.

Undang-undang Nomor 1 Tahun 1974 tentang Perkawinan; Lembaran Negara Republik Indonesia Tahun 1974 Nomor 1.

Undang-undang Nomor 23 Tahun 2002 tentang Perlindungan Anak; Lembaran Negara Republik Indonesia Tahun 2002 Nomor 109.

UNICEF. 2008. Child Marriage and the Law: Legislative Reform Initiative Paper Series. Februari 2008.

Valentina Sagala, R.. 2006. "Perdagangan Perempuan dan Anak dalam Pandangan Seorang Aktifis Perempuan”. Dalam Sulistyowati Erianto (ed.), Perempuan dan Hukum: Menuju Hukum yang Berperspektif Kesetaraan dan Keadilan. Cetakan I. Jakarta: Yayasan Obor Indonesia. 
Watoni, Saipul Arip. 2011. "Perceraian Akibat Pernikahan Dini: Studi Kasus di Kecamatan Kopang Kab. Lombok Tengah NTB Tahun 2006-2008”. Skripsi. Yogyakarta: UIN Sunan Kalijaga.

WCC Rifka Annisa. 2008. "Dating Violence”. Makalah disampaikan dalam Diskusi Perempuan dan Kekerasan Berbasis Gender yang diadakan oleh LP. Amanah PPRU I Gondanglegi Malang pada tanggal 27 Mei 2008.

al-Zuhaylī, Wahbah. 1985. Al-Fiqh al-Islāmī wa Adillatuh. Juz VII. Cetakan II. Beirut: Dār al-Fikr.

\section{REFERENSI DARI INTERNET}

Http://www.gondanglegi.malangkab.go.id, artikel "Data Penduduk"(akses tanggal 11 Mei 2011).

Http://www.langitperempuan.com, artikel "Dokurama 'Perempuan Nias' Angkat Nikah Dini Sebagai Kekerasan (23 Desember 2008)" (akses tanggal 11 Mei 2011).

Http://www.m.pikiran-rakyat.com, artikel "Hamil di Luar Nikah Picu Naiknya Kasus Pernikahan Dini (9 Juli 2009)” (akses tanggal 12 Mei 2011).

Http://www.ncjrs.gov, artikel "Chapter 9 Domestic Violence” (akses tanggal $14 \mathrm{Mei}$ 2011)

Http://www.pa-malangkab.go.id, artikel "Faktor-Faktor Penyebab Terjadinya Perceraian Tahun 2009" dan "Faktor-Faktor Penyebab Terjadinya Perceraian Tahun 2011" (akses tanggal 12 Mei 2011).

Http://www.pendis.kemenag.go.id, artikel “Direktori Pondok Pesantren 2008/2009: Prov. Jawa Timur Bagian I” (akses tanggal 11 Mei 2011).

Http://www.regional.kompas.com, artikel "Nikah Dini Marak di Kabupaten Malang (10 Februari 2009)” (akses tanggal 11 Mei 2011).

Http://www.suaramerdeka.com, artikel “Tinggi, Pernikahan Usia Dini di Kabupaten Malang (9 Nopember 2009)” (akses tanggal 11 Mei 2011).

Http://www.unicef.org, artikel “Child marriage” (akses tanggal 13 Mei 2011). 